\title{
Geochemistry of deep Tunguska Basin sills, Siberian Traps: correlations and potential implications for the end-Permian environmental crisis
}

\author{
S. Callegaro ${ }^{1}$ - H. H. Svensen ${ }^{1}$ - E. R. Neumann ${ }^{1}$ - A. G. Polozov² • D. A. Jerram ${ }^{1,3} \cdot$ F. M. Deegan ${ }^{4} \cdot$ S. Planke ${ }^{1,5}$. \\ O. V. Shiganova ${ }^{6} \cdot$ N. A. Ivanova ${ }^{6} \cdot$ N. V. Melnikov ${ }^{6}$
}

Received: 18 August 2020 / Accepted: 26 May 2021 / Published online: 8 June 2021

(c) The Author(s) 2021

\begin{abstract}
A vast portion of the plumbing system of the Siberian Traps Large Igneous Province (STLIP) is emplaced in the Tunguska Basin, where borehole data reveal ubiquitous and abundant sills with great lateral extension. These intrusions intersect Cambrian-Ordovician evaporite, carbonate and siliciclastic series, and locally coal-bearing Permian host rocks, with a high potential for thermogenic gas generation. Here we present new geochemical data from 71 magmatic and 4 sedimentary rock samples from the Tunguska Basin center and periphery, recovered from 15 deep sills intercepted by boreholes. The studied samples are all low-Ti basalt and basaltic andesites, confirming absence of high-Ti and alkaline STLIP magmatism in the Tunguska Basin. The sills derive from picritic parental melts produced by extensive melting of a mantle source with recycled crustal components below a thinned lithosphere (50-60 km), within the spinel stability field. The mantle source was dominantly peridotitic, with enriched pyroxenitic domains formed by recycled lower crust, in agreement with previous models for the main tholeiitic STLIP phase. Limited amounts (up to 5\%) of highly radiogenic granitoids or moderately radiogenic metapelites were assimilated in upper crustal magma reservoirs. After emplacement, sills intruded in Cambrian evaporites assimilated marlstones and interacted with the evaporitic host rocks, probably via fluids and brines. This is the first time that such process is described in subvolcanic rocks from all across the volcanic basin. The sills are correlated geochemically with the established chemostratigraphy for the on-craton STLIP lava piles and intrusions (Norilsk region). Sills correlated with the Morongovsky-Mokulaevsky Fm. and the Norilsk-type intrusions are the most voluminous, present all across the central Tunguska Basin, and bear the strongest evidence of interaction with evaporites. Massive discharge of thermogenic volatiles is suggested by explosive pipes and hydrothermal vent structures throughout the Tunguska Basin. We propose that this voluminous pulse of magmatism is a good candidate for the hitherto unidentified early intrusive phase of the STLIP, and may link the deep Tunguska basin sills to the end-Permian environmental crisis.
\end{abstract}

Keywords Sill geochemistry · Siberian Traps · Tunguska Basin · Magma-host rock interaction $\cdot$ Thermogenic gas generation $\cdot$ End-Permian crisis

Communicated by Othmar Müntener.

S. Callegaro

sara.callegaro@geo.uio.no

1 Centre for Earth Evolution and Dynamics, University of Oslo, Oslo, Norway

2 Institute of Geology of Ore Deposits, Petrography, Mineralogy and Geochemistry of Russian Academy, Moscow, Russia
3 DougalEARTH Ltd., Solihull, UK

4 Department of Earth Sciences, Natural Resources and Sustainable Development, Uppsala University, Uppsala, Sweden

5 Volcanic Basin Petroleum Research (VBPR), Oslo, Norway

6 Geophysics and Mineral Resources, Siberian Scientific Research Institute of Geology, Novosibirsk, Russia 


\section{Introduction}

The Siberian Traps Large Igneous Province (STLIP; ca. 251-252 Ma; Fig. 1), synchronous with the end-Permian mass extinction (Burgess et al. 2017; Dal Corso et al. 2020) and home to world-class $\mathrm{Cu}-\mathrm{Ni}-\mathrm{PGE}$ ore deposits (Ryabov et al. 2014), is one of the most intensely studied LIPs. However, due to limited accessibility, we still lack geochemistry and age information on sills constituting the non-exposed and deep-seated portion of the STLIP in the Tunguska Basin (TB).

The intrusive components of LIPs are attracting increasing attention from the scientific community since thermogenic production of volatiles from the country rocks by magma/host rock interaction was recognized as volumetrically significant in the appraisal of LIPs gas emissions (Svensen et al. 2004, 2009, 2018). The numeorous pipes/vents and volcaniclastic products within the STLIP suggest a link between its sub-volcanic plumbing system and surface products (Jerram et al. 2016; Polozov et al. 2016), adding further evidence for a significant host basin influence in the STLIP evolution. Volcanic basins and LIP plumbing systems are, therefore, key players for linking magmatic events, gas production, and environmental crises. For the atmospheric impact of a LIP, the tempo of volcanism is a crucial factor, perhaps more so than a cumulative appraisal of the volumes of volcanics and volatiles involved (Sprain et al. 2019). As much as they can be considered geologically brief events, LIPs usually last much longer than the related extinction intervals $(<100$ kyr). Hence, the extinction-triggering event is probably a shorter subset of an entire LIP episode (Burgess et al. 2017). Recent U-Pb geochronology was focused on providing a high-precision reassessment of the STLIP, looking at timing of intrusive vs. effusive activity (Burgess and Bowring 2015; Burgess et al. 2017; Augland et al. 2019). Most ages obtained for the intrusive phase of the STLIP post-date the extinction interval, with the exception of the Norilsk 1 and Karaelakh intrusions (Burgess et al. 2014; Burgess and Bowring 2015). However, the start of intrusive activity is not constrained, hence it is possibile that the extinction-triggering part of the Siberian Traps is a yet undetected or unsampled early intrusive batch (Burgess
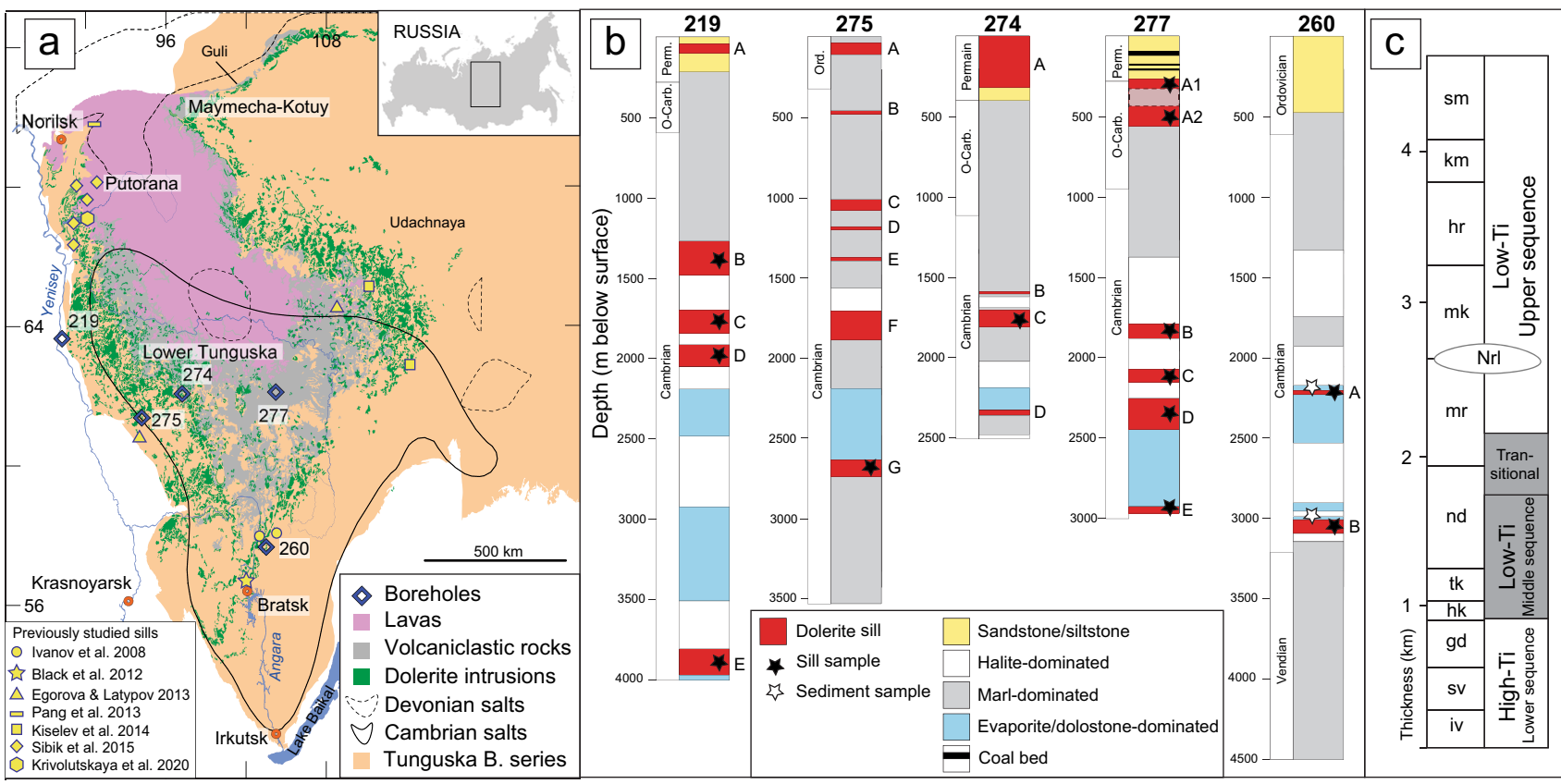

Fig. 1 a Borehole locations (blue diamonds) are plotted on a map of the Siberian Traps LIP (modified after Svensen et al. 2018), along with locations of previously studied sills (yellow symbols). The Siberian Traps crop out in several regions. Four of these are roughly oncraton, namely Norilsk, Putorana, Maymecha-Kotuy and Nizhnaya Tunguska (translated to Lower Tunguska). Other expressions of the Siberian Traps magmatism appear in regions off-craton, such as the West Siberian Basin, and the Taimyr Peninsula in the North (Reichow et al. 2005, 2016). b Schematic logs of the investigated boreholes organized from W to E from 219 to 277 ; borehole 260 is placed last for its detached southern position. Sampled sills are indicated by black stars, sampled host rocks by white stars. $\mathbf{c}$ Lava formations and chemostratigraphic classification of STLIP tholeiites in the Norilsk area-simplified stratigraphic log (modified after Ivanov et al. 2008). Names of the formations: iv - Ivakinsky; sv - Syverminsky; gd Gudchikhinsky; hk - Khakanchansky; tk - Tuklonsky; nd - Nadezhdinsky; mr - Morongovsky; mk - Mokulaevsky; hr - Kharaelakhsky; km - Kumginsky; sm - Samoedsky. Nrl - Norilsk 1 intrusion, positioned after Pavlov et al. (2019) 
et al. 2017). Increased penetration of the subsurface with boreholes (Svensen et al. 2018) recently gave a more complete picture of the intrusive STLIP in the TB. Sills comprise a significant volume of the STLIP (between 37 and 44\%; Vasiliev et al. 2000; Ross et al. 2005), and they intercept volatile-rich lithologies (evaporite, marl, limestone and coal-bearing siliciclastics) with high potential for thermogenic gas discharge into the end-Permian atmosphere (Svensen et al. 2018). The TB sills are excellent candidates for representing the undetected intrusive pulse invoked by Burgess et al. (2017), but evidence for their interaction with host rocks is scarce (Svensen et al. 2009), and no geochemical data is yet available for deep sills from localities covering a vast part of the Tunguska Basin. We have analyzed sill samples (chips and cores) from boreholes drilled to $4 \mathrm{~km}$ depth in 5 localities distributed across the central part of the TB. This geochemical study sheds light on the petrogenesis of these sills and their interaction with crustal rocks. Hinging on proposed geochemical correlations with the chemostratigraphy etablished in the Norilsk region, we discuss the timing of relative emplacement of the sills network and its implications on the STLIP thermogenic gas production scenarios.

\section{Geological context for the Tunguska Basin and chemostratigraphy of the Siberian Traps}

The Siberian Traps LIP includes large volumes of basaltic lavas (Fedorenko et al. 1996; Reichow et al. 2005) and volcaniclastic products (Jerram et al. 2016), as well as a vast sub-volcanic plumbing system of dikes and sills, connected to explosive pipe and hydrothermal vent structures (Fig. 1; Polozov et al. 2016; Svensen et al. 2009, 2018). The STLIP crops out in four main regions, mostly within the Siberian Craton (Sharma 1997): Norilsk, Putorana, Maymecha-Kotuy and Nizhnaya (Lower) Tunguska (Fig. 1). Off-craton, the STLIP extends to the West Siberian Basin (buried basalts; Saunders et al. 2005; Reichow et al. 2005) and in the Taimyr peninsula (Reichow et al. 2016; Augland et al. 2019). Volume estimates for the STLIP products vary widely, with a minimum of 2 million $\mathrm{km}^{3}$ (Vasiliev et al. 2000). Preserved and original volumes are difficult to constrain due to the remoteness of most outcrops and to the fact that a significant part of the province resides below the surface (Reichow et al. 2002, 2005, 2009; Svensen et al. 2018). The short-lived main (tholeiitic) pulse of volcanic and subvolcanic magmatism was dated to ca. 252.3-251.3 Ma (Burgess and Bowring 2015; Augland et al. 2019), and straddles the extinction interval at the Permo-Triassic boundary and the concomitant negative $\delta^{13} \mathrm{C}$ excursion (dated in Meishan to $251.941 \pm 0$. 28-251.88 $\pm 0.28 \mathrm{Ma}$; Burgess et al. 2014).
The Tunguska volcanic basin is an extensive system of interconnected sill complexes and associated hydrothermal vents. The sills intruded the vast and deep $(3-12.5 \mathrm{~km})$ Tunguska sedimentary Basin, composed of Riphean to Early Permian sedimentary series, including evaporitic, siliciclastic, carbonatic, and hydrocarbon-bearing lithologies, in addition to thick coal deposits. The basement below the TB does not crop out, but Proterozoic gneiss and leucogranites were sampled as xenoliths (Czamanske et al. 2000) by explosive pipes close to Norilsk. Sills are abundant throughout the TB, and locally constitute up to $65 \%$ of the stratigraphy (Kontorovich et al. 1997; Ulmishek 2001; Svensen et al. 2018). These sills mainly crop out along the margins of the province and along the main rivers, but are intersected by numerous stratigraphic, exploratory and commercial boreholes. Svensen et al. (2018) reported sills in $93.5 \%$ of 284 boreholes (including the 6 boreholes studied here), concluding that sills are present everywhere beneath the TB, although they may pinch out laterally.

The effusive STLIP started as a low-volume subalkaline high-Ti phase $\left(\mathrm{TiO}_{2}>2 \mathrm{wt} \%\right.$; Lower Sequence), continued as a low-Ti tholeiitic series (Middle and Upper Sequence) and closed with a very heterogeneous alkaline phase. Tholeiitic and alkaline magmas from the Siberian Traps originated from different mantle lithologies and sources and followed separate paths and processes en route to the surface (Arndt et al. 1998; Elkins-Tanton et al. 2007; Sobolev et al. 2011). This interpretation is mainly based on studies of the lava sequences in the Norilsk area, where chemostratigraphic units and magma types were defined based on major and trace element and isotope data for the lavas (Lightfoot et al. 1990, 1993; Wooden et al. 1993; Fedorenko et al. 1996), and for the local intrusive bodies (Naldrett et al. 1992; Hawkesworth et al. 1995; Arndt et al. 2003). Similar signatures can be tracked over long distances in the STLIP (Reichow et al. 2005; Augland et al. 2019), and it is not uncommon for LIP magmas to show uniform geochemical compositions over large areas, even over $>1000 \mathrm{~km}$ distance (Marzoli et al. 2018; Bédard et al. 2020). We note that as more data on the STLIP became available, independent names for different regions were assigned to the various magma units (cf. Fig. 2 in Sharma 1997 and Sibik et al. 2015). Here, we use the nomenclature defined from the Norilsk region studies, which can be taken as type-locality because it represents the most complete section of volcanic rocks in the STLIP.

Near Norilsk, eleven lava formations (see summary table in Fig. 1c; Fedorenko et al. 1996; Lightfoot et al. 1990, 1993; Wooden et al. 1993; Hawkesworth et al. 1995) and five major magma types (Naldrett et al. 1992) were defined. Lightfoot et al. (1990, 1993) grouped the lavas into Lower (high-Ti), Middle-Transitional (low-Ti), and Upper (low-Ti) sequences (Fig. 1c). The Lower, highTi sequence comprises the alkaline/subalkaline, high 


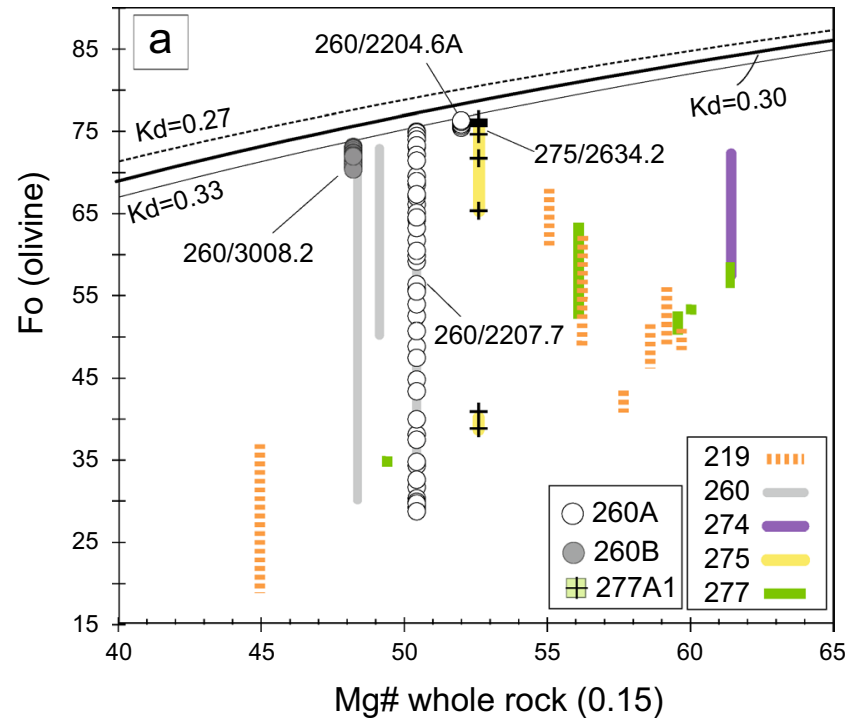

Fig. 2 Mineral-whole rock Fe-Mg equilibrium diagrams for olivine (a) and clinopyroxene (b). Mineral compositions (Fo and Mg\#) are

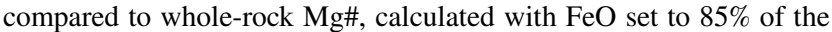
total iron in the whole-rock. The curves display the range of equi-

magnesian Ivakinsky, Syverminsky and Gudchikhinsky formations. Above these, the Middle-Transitional low-Ti sequence includes the Tuklonsky and Nadezhdinsky lava suites. These are followed by the Upper sequence, including five suites of mainly tholeiitic basalts (Morongovsky to Samoedsky fromations) with uniform geochemical signatures, and representing the main tholeiitic pulse of the STLIP. The intrusions found in the Norilsk region have been classified into five types and correlated with the lava piles (Naldrett et al. 1992; Hawkesworth et al. 1995; Arndt et al. 2003; Pavlov et al. 2019; Yao and Mungall 2021). The most prominent intrusive types are the dolerites and differentiated intrusions (type 3 ), spanning the entire Norilsk region, the ore-bearing Norilsk-type intrusions (5A), and the Lower Talnakh-type (5B; Naldrett et al. 1992). Type 3 intrusions are further subdivided and correlated with specific Upper series formations, as is the case for the Ambarninsky type II dolerites, correlated with the Kharaelakhsky Fm. (Hawkesworth et al. 1995). Lower Talnakh-type intrusions are geochemically similar to the Middle sequence Nadezhdinsky basalts (enriched trace elements ratios and $\mathrm{Nd}$ isotopes, low $\mathrm{Cu}$ ), to the West Siberian Basin and Taimyr basalts (Reichow et al. 2005, 2016). Norilsk-type intrusions are geochemically akin to the Upper Sequence Morongovsky-Mokulevsky basaltic suites, with which they are coeval (Pavlov et al. 2019; Burgess and Bowring 2015). The last phase of the STLIP, intrusive and effusive, is strongly alkaline, and so far documented only in the Maymecha-Kotuy region (Arndt et al.

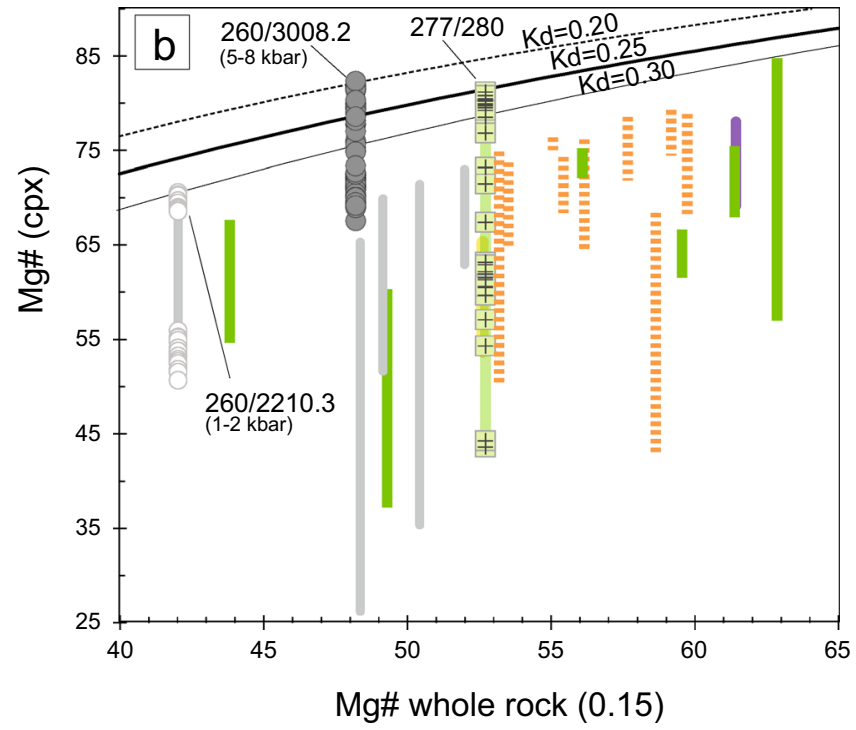

librium compositions between mineral and melt for $\mathrm{Fe}-\mathrm{Mg}$ partition coefficients of $0.30 \pm 0.03$ for olivine (Roeder and Emslie 1970) and $0.25 \pm 0.05$ for clinopyroxene (cf. Bédard 2014). The mineral chemistry full dataset is available in Supplementary information 2

1998; Sobolev et al. 2009b; Fig. 1) and in the Taimyr peninsula (Vernikovsky et al. 2003; Augland et al. 2019).

Despite some still unexplained features such as the lack of regional uplift, there is general consensus on a plume-derived origin for this LIP (Sobolev et al. 2011 and references therein). However, different petrogenetic histories are reflected by the geochemistry of the STLIP rocks. The Lower sequence highTi lavas were interpreted as derived from small degree deep melting of pure pyroxenite in the presence of garnet (Sobolev et al. 2011). Lavas of the Upper and Middle-Transitional lowTi sequences reflect shallower and more extensive melting of a dominantly peridotitic mantle source. These magmas show arc-like features (e.g. low $\mathrm{Nb}$, high $\mathrm{Pb}, \mathrm{Sr}, \mathrm{Ba}$, fairly radiogenic $\mathrm{Sr}$ and $\mathrm{Nd}$ isotopes) that have been explained as either inherited directly from a subduction-modified lithospheric mantle (Fedorenko et al. 1996; Lightfoot et al. 1993; Ivanov et al. 2008), or as an effect of crustal contamination in deep crustal magma chambers (Wooden et al. 1993; Arndt et al. 2003; Reichow et al. 2005). High temperature deep melting of a volatile-rich source produced the last alkaline phase of the STLIP (Elkins-Tanton et al. 2007).

\section{Materials and methods}

\section{Sampled borehole}

The samples analyzed in this study were collected from five boreholes (Fig. 1b; coordinates in Supplementary 
information 1) housed in the core storage of the Siberian Scientific Research Institute of Geology, Geophysics and Mineral Resources (Novosibirsk). We logged, sampled and studied selected intervals in the Nizhneimbakskaya 219 borehole (Total depth TD $4000 \mathrm{~m}$ ), Zheldonskaya 260 (TD 4509 m), Suringdinskaya 274 (TD 2679 m), Majgunnskaya 275 (TD $3500 \mathrm{~m}$ ) and Verkhneilimpejskaya 277 (TD $3030 \mathrm{~m}$ ). The sills intercepted by each borehole are identified by letters, starting from the shallowest sill as "A" (Fig. 1b). A total of 71 samples were studied from 15 individual sills. Borehole 219 was drilled at the western limit of the TB, where only intrusive products of the STLIP are preserved. Five sills were intercepted, for a cumulative thickness of $710 \mathrm{~m}$. All but the shallowest one (not available for sampling) were emplaced in Cambrian evaporites, including halite, carbonates and anhydrite. Boreholes 274 and 275 were drilled SE of 219, where intrusive and volcanoclastic products are preserved. Borehole 274 intercepted 4 sills. The thickest sill (minimum $310 \mathrm{~m}$; not sampled) crops out and intrudes Permian clastic, organic-rich sediments. The three sills below are thinner (total thickness $145 \mathrm{~m}$ ), and intrude Cambrian evaporites. Seven sills are found along borehole 275 (total thickness of $478 \mathrm{~m}$ ). The shallowest sill (A) intrudes Ordovician marls. The remaining 6 sills intrude marl- and dolostone-dominated Cambrian series. Only the deepest sill was available for sampling. Borehole 277 was drilled ca. $500 \mathrm{~km}$ to the east of 275 , in an area with abundant pyroclastic deposits and breccia pipes, and it intercepted 5 sills (Svensen et al. 2018 reported $707 \mathrm{~m}$ as cumulative sill thickness, which is a minimum value because the borehole stops within sill 277E). The shallowest sill is emplaced in Silurian marls and is recorded in the logs as a single sill. However, sedimentary cuttings recovered between 325 and $440 \mathrm{~m}$, suggest that sill 277A is in fact a composite intrusion of two sills separated by sedimentary rocks (hereinafter referred as sills 277A1 and 277A2). The other 4 sills are emplaced in Cambrian evaporites (halite and dolostone). Borehole 260 was drilled in the south, ca. $500 \mathrm{~km}$ south of 277 and $200 \mathrm{~km}$ north of Bratsk, in an area heavily pierced by pipe structures (Svensen et al. 2018). Two thin sills (total thickness $107 \mathrm{~m}$ ) were intercepted within Cambrian evaporites (halite and dolostone).

\section{Analytical techniques}

Samples selected for geochemical analyses were either core fragments or cuttings selected from the freshest available material (Fig. S1a, b;e; note that S refers hereinafter to figures included in Supplementary information 1). Any visible alteration patches and fracture sides were eliminated by saw from the cores. Cuttings of $1-5 \mathrm{~mm}$ were carefully hand-picked under binocular microscope after sieving to avoid fragments of other origin. Chips coarser than $2 \mathrm{~mm}$ were reduced in size under a fly press, using plastic bags and plexiglass plates to avoid contact with the press metal. Samples were repeatedly washed with deionized water in ultrasonic bath and milled using an agate ball-mill.

Whole-rock major and trace elements were measured by Inductively Coupled Plasma Optical Emission (ICP-OES) or ICP Mass Spectrometry (ICP-MS) using the 4Lithores method at Activation Laboratories Ltd (Canada). Sample powders were mixed with a flux of lithium metaborate and tetraborate and fused in an induction furnace and mixed with 5\% nitric acid until completely dissolved. Major elements and selected trace elements ( $\mathrm{Ba}, \mathrm{Be}, \mathrm{Sc}, \mathrm{Sr}, \mathrm{V}$, and $\mathrm{Zr}$ ) were analyzed by ICP-OES (Thermo Jarell-Ash ENVIRO II ICP or a Varian Vista 735 ICP), whereas the remaining trace elements were analyzed by ICP-MS (Perkin Elmer Sciex ELAN 6000, 6100, or 9000 ICP/MS). Along with the samples, certified reference materials, a method reagent blank, and sample replicates were also analyzed (Supplementary information 2). Calibration was performed using six prepared USGS and CANMET certified reference materials for the ICP-OES analysis, and 12 for the ICP-MS analysis. For the ICP-OES analysis, one of the standards was analyzed for every group of ten samples, while the ICP-MS instrument was recalibrated every 40 samples. Analytical uncertainties for major elements are estimated at $<5 \%$. For trace elements, uncertainties are $100 \%$ at the detection limit, $20 \%$ at 10 times the detection limit, and $10 \%$ at 100 times the detection limit (Supplementary information 2). Loss on Ignition (LOI) was determined by igniting sample powders in a chamber furnace at $1000{ }^{\circ} \mathrm{C}$ for $2 \mathrm{~h}$, and weighing the samples before and after heating.

Whole-rock $\mathrm{Sr}-\mathrm{Nd}$ isotopic compositions were determined for a subset of 35 samples on the same sample aliquots analyzed for major and trace elements, using a Thermal-Ionization Mass Spectrometer (TIMS; Finnigan MAT 262) at the Bergen Geoanalytical Facility, University of Bergen, following the procedures described in Pin et al. (1994). Pulverized samples were heated in a chamber furnace to $1000{ }^{\circ} \mathrm{C}$ for $1 \mathrm{~h}$ and decomposed in $\mathrm{HF}-\mathrm{HNO}_{3}$ in Savillex beakers on a heating plate. The dissolved and dried samples were re-dissolved in $2 \mathrm{~N} \mathrm{HNO}_{3}$ prior to chromatographic separation. $\mathrm{Sr}$ and $\mathrm{Nd}$ were separated from matrix elements by ion selective extraction chromatography on three different chromatographic materials supplied by Eichrom. Rare-Earth Elements (REE) were first retained on TRU Spec columns. In the next step, the retained REE elements were purified on LN Spec resin to selectively recover Nd. After removal and recovery of REE, Sr was extracted from matrix effluent by the ion specific resin, $\mathrm{Sr}$ Spec. $\mathrm{Nd}$ and $\mathrm{Sr}$ isotopic rations were corrected for mass fractionation using ${ }^{146} \mathrm{Nd} /{ }^{144} \mathrm{Nd}$ ratio of 0.7219 and ${ }^{88} \mathrm{Sr} /{ }^{86} \mathrm{Sr}$ ratio of 8.375209. Repeated measurements of the Strontium Carbonate Standard (SRM987) at the time of analysis (May 2018 and September 2018) yielded 
an average ${ }^{87} \mathrm{Sr} /{ }^{86} \mathrm{Sr}$ ratio of $0.710229 \pm 8(2 \mathrm{SD} ; n=3)$ and $0.710237 \pm 13(2 \mathrm{SD} ; n=7)$, respectively. Hence, ${ }^{87} \mathrm{Sr} /{ }^{86} \mathrm{Sr}$ measured values for the samples were adjusted for daily variations between the measured values of SRM987 and the reference ${ }^{87} \mathrm{Sr} /{ }^{86} \mathrm{Sr}$ value of this standard (0.710240). Repeated isotopic measurements of the La Jolla Reference Standard at the time of analysis yielded an average ${ }^{143} \mathrm{Nd} /{ }^{144} \mathrm{Nd}$ ratio of $0.511850 \pm 11(2 \mathrm{SD} ; n=2)$ and $0.511850 \pm 9(2 \mathrm{SD} ; n=5)$, equivalent to the accepted reference value of 0.511850 for La Jolla, negating the need for further correction. Analytical errors $(2 \sigma)$ for the measured $\mathrm{Sr}$ isotopic ratios are reported in Table 1 and vary between 0.000006 and 0.000009 . The uncertainties for the values re-calculated to 251 Ma taking into account radiogenic in-growth are propagated including uncertainties on trace element determinations for $\mathrm{Rb}$ and $\mathrm{Sr}$ and on the decay constant. They vary between 0.000011 and 0.000089. Analytical errors for ${ }^{143} \mathrm{Nd} /{ }^{144} \mathrm{Nd}$ are also reported in Table 1 and vary between 0.000005 and 0.000013 . For two sedimentary samples ${ }^{143} \mathrm{Nd} /{ }^{144} \mathrm{Nd}$ values were not measured due to extremely low $\mathrm{Nd}$ concentration.

Detailed chemical traverses and spot analyses on selected crystals were obtained using a Cameca SX100 electron microprobe at the University of Oslo, operated in wavelength-dispersive (WDS) mode at $15 \mathrm{kV}, 15 \mathrm{nA}$ for most mineral phases and at $10 \mathrm{nA}$ for plagioclase, with a focused electron beam and a counting time of $10 \mathrm{~s}$ on peak. Matrix corrections were performed according to the PAP procedure implemented in the Cameca software (Merlet 1994). Calibration standards were as follows: wollastonite $(\mathrm{Si}, \mathrm{Ca})$, orthoclase $(\mathrm{K})$, albite $(\mathrm{Na})$, synthetic $\mathrm{Al}_{2} \mathrm{O}_{3}(\mathrm{Al})$, pure iron metal $(\mathrm{Fe})$, pyrophanite $(\mathrm{Mn}, \mathrm{Ti})$ synthetic periclase $(\mathrm{Mg})$, eskolaite $(\mathrm{Cr})$, nickel oxide $(\mathrm{Ni})$, synthetic alforsite $(\mathrm{Cl})$, fluorite (F), and Durango apatite (Ca, P, F). Where possible, $\mathrm{F}, \mathrm{Cl}, \mathrm{Na}$, and $\mathrm{K}$ were analyzed first.

\section{Petrography and mineral chemistry}

Sill samples vary in texture from microporphyritic (Fig. S1f, rare), with microphyric groundmass, to fine- or mediumgrained ophitic dolerites (Fig. S1c, d; common), with a tendency for clinopyroxene to form oikocrysts. Coarser grain size is observed for the deepest sills (e.g. 219E; 277E; Fig. S1a), where some medium-grained gabbros are found (Fig. S1a). For the sills with numerous available samples (e.g. 219C, 277B, 277C), a shift in grain size within a single sill is recognized, from fine-grained or porphyritic at the margins to medium-grained, gabbroic, at the center, although never exceeding $5 \mathrm{~mm}$ grain size for the largest crystals.

The sill mineralogy is typically doleritic, with ubiquitous clinopyroxene and plagioclase, frequent olivine and rare orthopyroxene. Oxides (ilmenite and Ti-magnetite) are present, in very large (occasionally poikilitic) or small crystals, sometimes showing dendritic or resorbed textures. Magmatic sulfides are rare and small, but pyrite and chalcopyrite are regularly observed occupying large secondary veins, or pockets between larger crystals in coarse-grained rocks (arrow in Fig. S1a), or at the contact with the host sedimentary rocks, where they can reach $\mathrm{mm}$ size (arrow in Fig. S1b). The large clinopyroxene oikocrysts are sometimes visible macroscopically as rounded domains (Figs. S1d, S2). Oikocrystic augite encloses randomly oriented plagioclase laths and very rarely olivine crystals, but never opaque minerals (Fig. S1c, d). In some samples, plagioclase of different generations appears, as small crystals included in the pyroxenes, but also as larger, zoned crystals. In various samples, evolved micropegmatites occupy late-stage interstitial pockets isolated among larger crystals. The mineralogy of these domains is typical of evolved (granitic) melts, with quartz, (Cl-rich) biotite, chlorite, K-feldspar, apatite and small occurrences of incompatible-element-bearing minerals (e.g. zircon, baddeleyite, sphalerite). The crystallization sequence of the primary dolerite assemblage as suggested by the textures is: olivine, plagioclase, pyroxenes, and opaque phases, followed by crystallization of the evolved interstitial domains, for which euhedral quartz, high- $\mathrm{Cl}$ in biotite and the presence of chlorite suggests that crystallization straddled orthomagmatic and hydrothermal stages. Detailed mineral chemistry of the contacts with host rocks and of the latestage pockets will be addressed in a separate contribution.

In several dolerites, minor alteration has caused substitution of plagioclase by clay minerals or sericite and local growth of iddingsite and serpentine at the expense of olivine. Chlorite and amphibole sometimes replace pyroxene. Chlorite appears also as a substitute for biotite. Late-stage hydrothermal fluids precipitated calcite, scapolite, amphiboles and phyllosilicates in millimetric to centimetric veins. Two samples from a magmatic enclave, possibly an autolith, were found within sill 219D (Fig. S2). This enclave is relatively coarse-grained (up to $5 \mathrm{~mm}$ crystals), with a melanocratic portion (sample 219-2007.0A), dominated by dark blades of amphibole and few interstitial pink and white feldspars, and a leucocratic portion (sample 219-2007.0B), very altered, volumetrically dominated by feldspar, and showing some porosity. Thin sections were made through the dolerite-enclave contacts, for both portions (Fig. S3), highlighting a magmatic (possibly cumulitic) texture for the enclave, which is also strongly altered with sericitized plagioclase, and pyroxene substituted by chlorite and amphibole. The surrounding dolerite is finegrained and well preserved, except in areas close to fractures, where chlorite and secondary biotite have developed. Four sedimentary host rocks from borehole 260 were analyzed. Sample 260/2200 is an impure dolomitic limestone, 260/2998.45 and 260/3000.3 are dolostones, and $260 / 3001.2$ is a mixed anhydrite/halite evaporite. These 


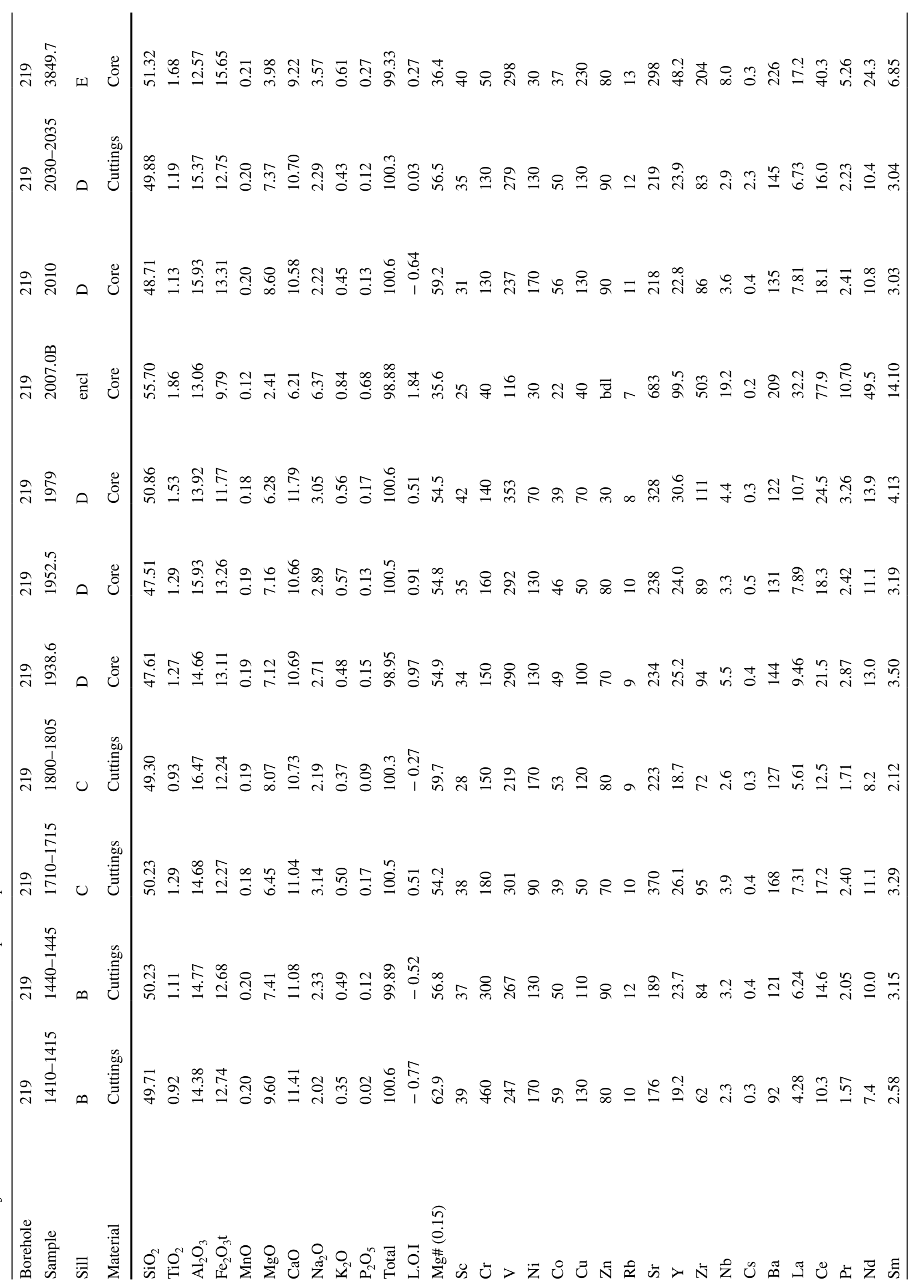




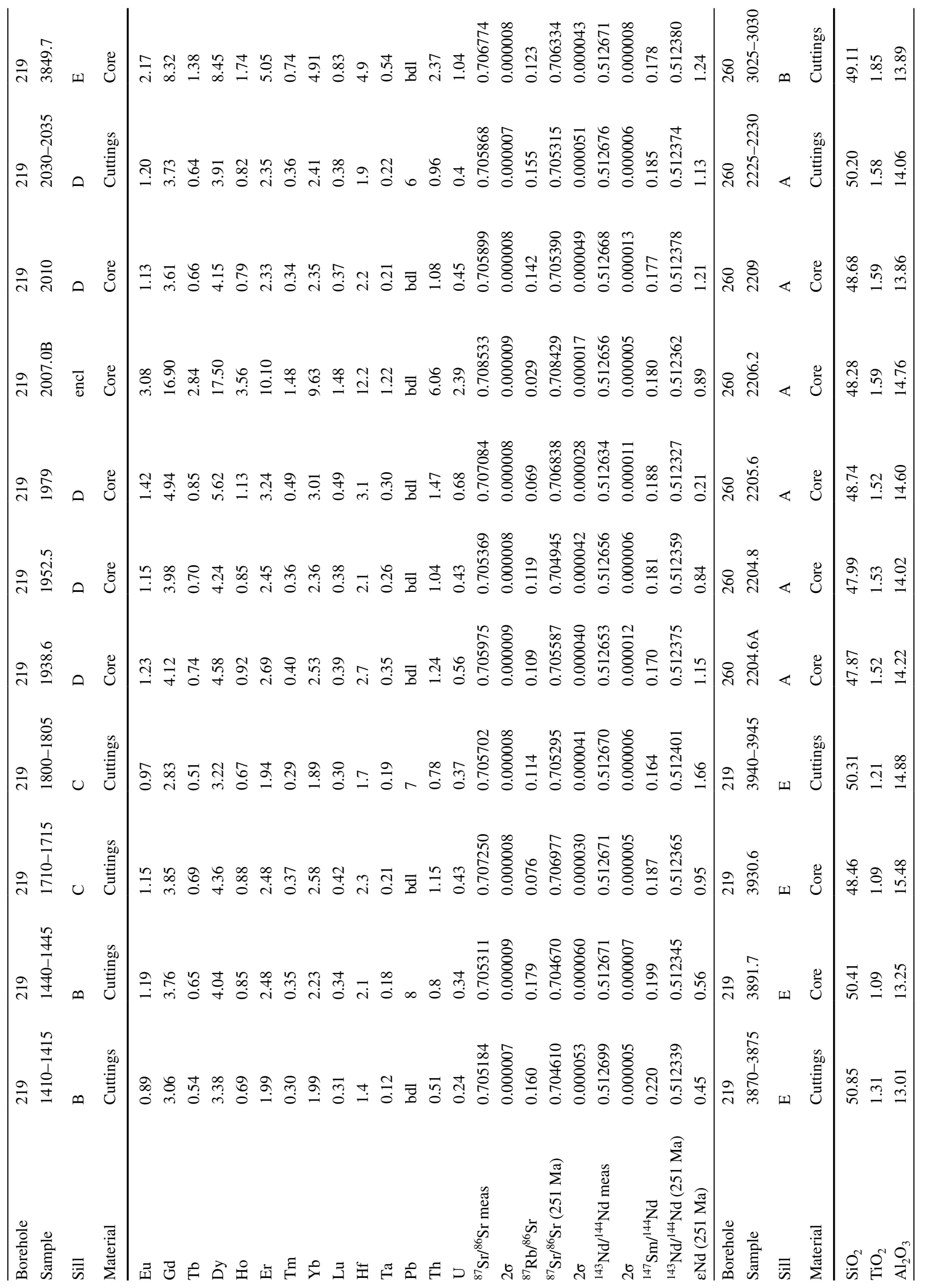




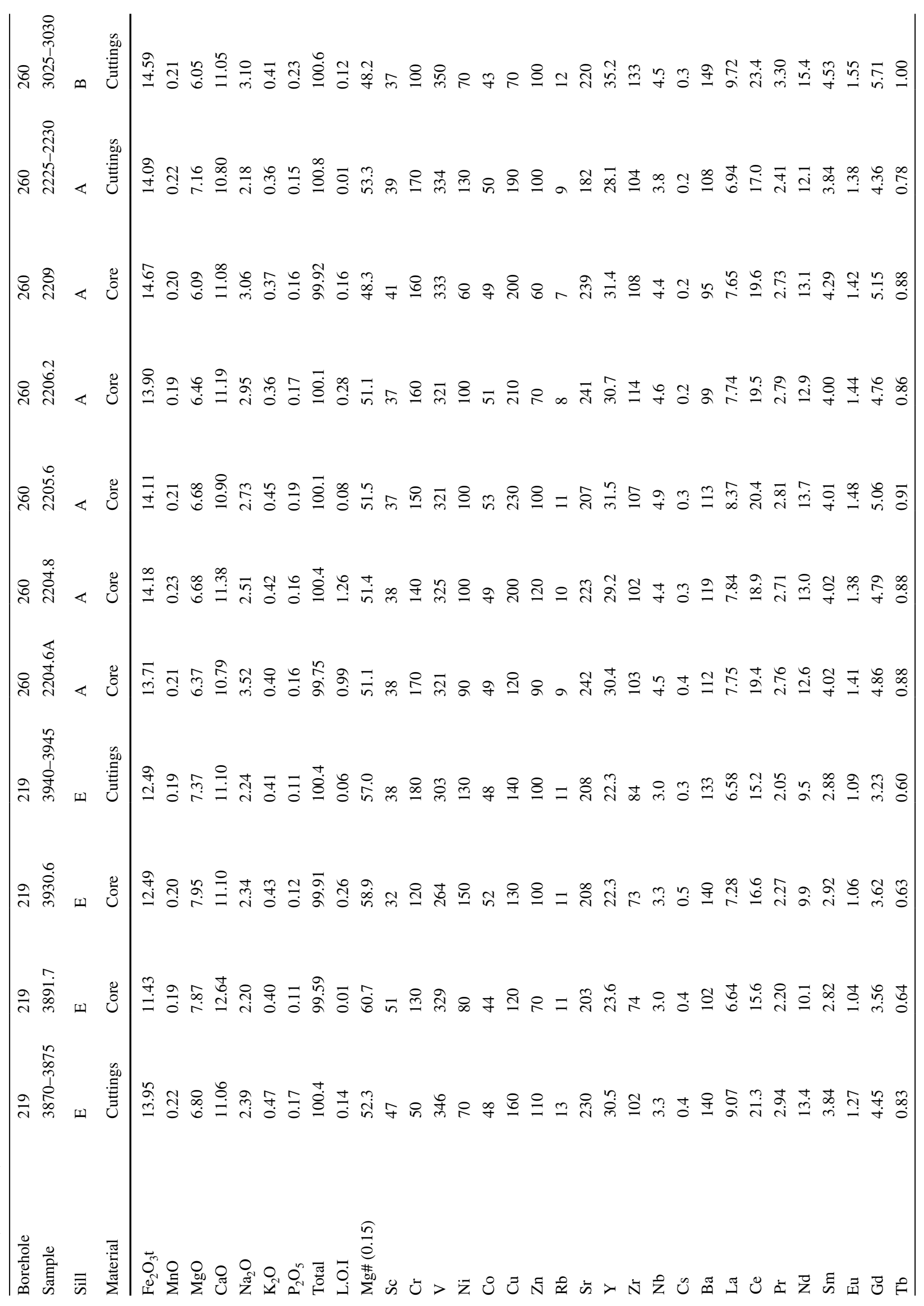




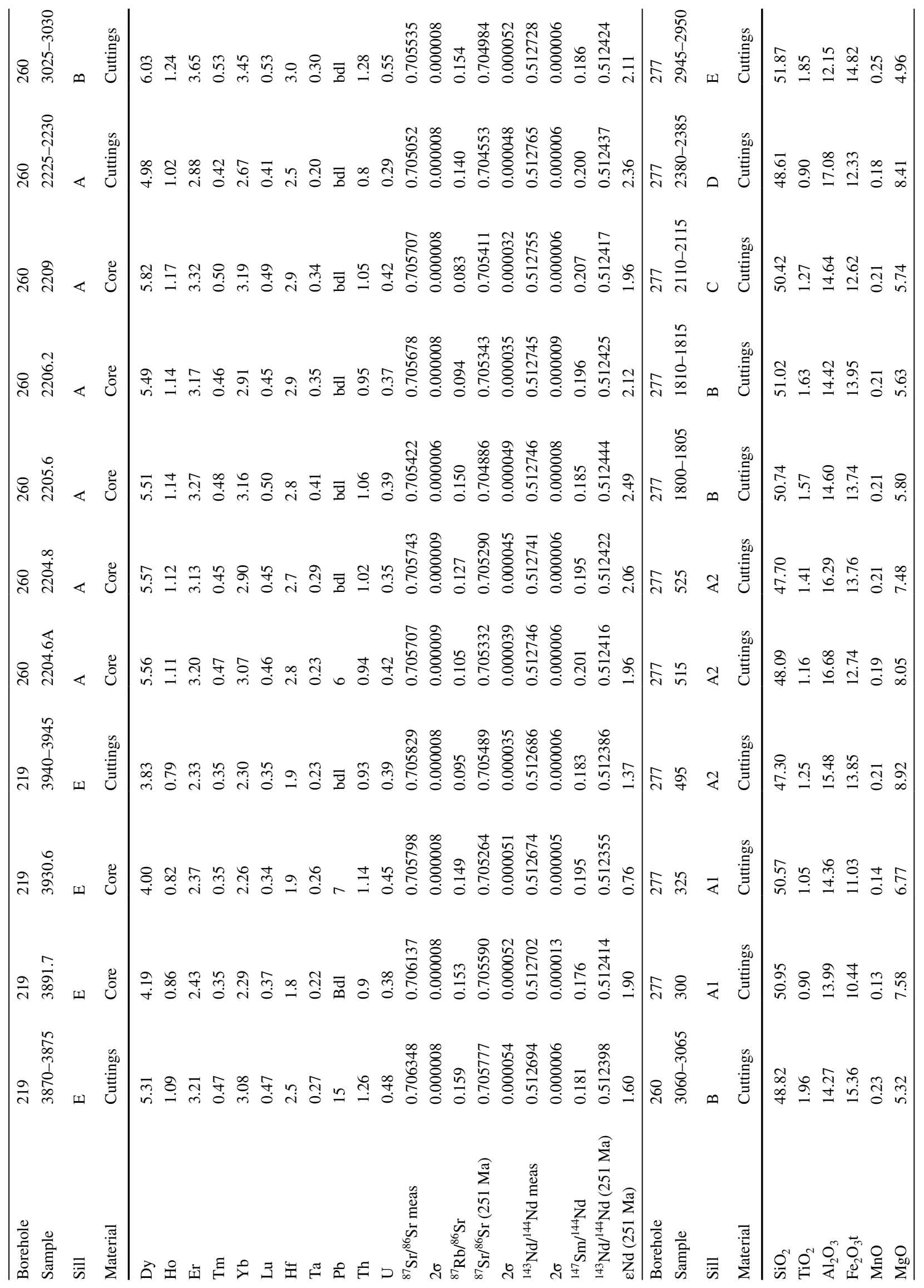




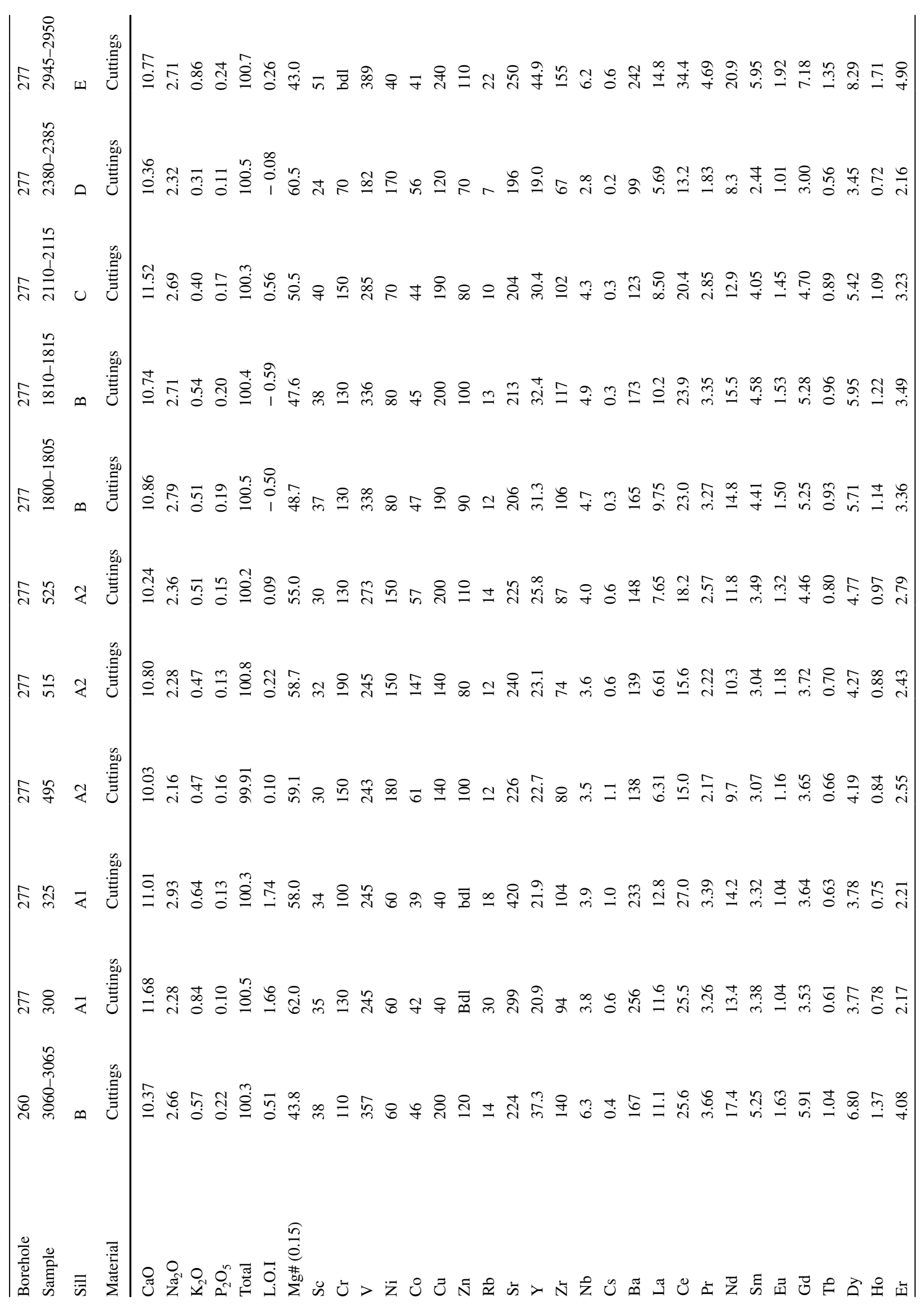




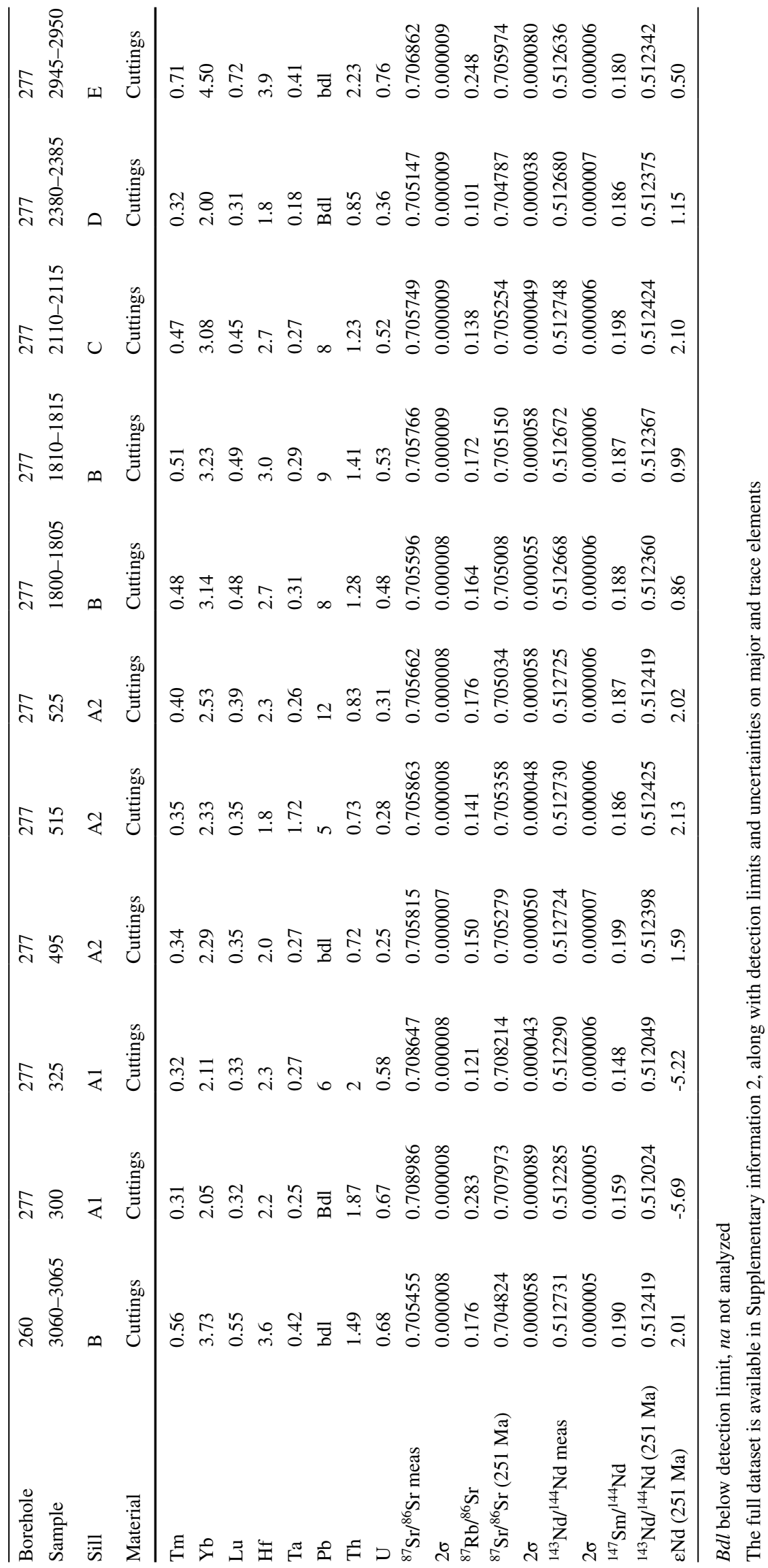


samples do not show strong compositional or textural evidence of contact metamorphism, but many contact zones in hand sample (from borehole 260 as well as others studied here) show features of contact phenomena including re-crystallized reaction zones, fracturing at contact margins, and concentration of sulfides (Fig. S1b).

Olivine crystals were analyzed in 20 samples (Supplementary information 2). Olivine shows large compositional variations, ranging in forsterite between $\mathrm{Fo}_{86}$ and $\mathrm{Fo}_{19}$. Most olivine crystals have compositions around $\mathrm{Fo}_{50-70}$ in our dolerites, and most crystals are unzoned or show mild zonations. Most olivine crystals are in disequilibrium with the whole rock, for a Fe/Mg olivine/melt partition coefficient of $0.30 \pm 0.03$ (Roeder and Emslie 1970; Fig. 2a), except those from sills 260A-B and 275G. Normal zoning is observed for sample $260 / 2207.7\left(\mathrm{Fo}_{75-29}\right), 219 / 1973.9$ $\left(\mathrm{Fo}_{34-27}\right)$ and $219 / 1976.2\left(\mathrm{Fo}_{62-49}\right)$. Olivine crystals from sample 260/3025-3030 are inversely zoned $\left(\mathrm{Fo}_{54-74}\right)$, with the rims in equilibrium with the whole rocks and the cores less Mg-rich. Olivine crystals from rapidly cooled (chilled margin) samples from sill 260A-B contain melt inclusions.

All analyzed dolerites contain pyroxene. Augite $\left(\mathrm{Wo}_{17-50} \mathrm{En}_{49-46} \mathrm{Fs}_{42-9}\right)$ is the most common pyroxene phase, with rare occurrence of subcalcic augite. Considering a $\mathrm{Fe}-\mathrm{Mg}$ partition coefficient of $0.25( \pm 0.05$; Bédard 2014), most augites are not in equilibrium with the whole rock, having lower $\mathrm{Mg} \#$ than predicted by equilibrium conditions, except those from 260/2210.3 and 260/3008.2 (Fig. 2b). Most clinopyroxene crystals are unzoned, some present a slight normal zoning ( $\mathrm{Fe}$ enriched at the rims, e.g. 260/2207.7 from $\mathrm{Wo}_{44} \mathrm{En}_{39} \mathrm{Fs}_{16}$ to $\mathrm{Wo}_{37} \mathrm{En}_{26} \mathrm{Fs}_{36}$ ), and augites from 260/3008.2 show a complex zoning (decreasing $\mathrm{Ca}-\mathrm{Mg}$ and increasing Fe from core to intermediate portions of the crystal, followed by a strong inverse zoning). Similar inverse zoning was observed for olivine from the same rock. Augites from 260/3008.2 are rich in $\mathrm{Na}_{2} \mathrm{O}(0.37-1.46$ wt.\%, as opposed to $<0.45$ for the other crystals, some groundmass crystals excepted), $\mathrm{TiO}_{2}$ (up to $2 \mathrm{wt} . \%$ ), and $\mathrm{CaO}$ (20.1-25.4 wt.\%). Orthopyroxene $\left(\mathrm{Wo}_{1-5} \mathrm{Fs}_{42-71} \mathrm{En}_{56-27}\right)$ is present in samples 219/3891.7, 219/3930.6 and 277/495 and was observed as microcrystalline matrix phase in sample 260/3025-3030. We calculated crystallization pressures of $8 \pm 3 \mathrm{kbar}$ for clinopyroxene from sill $260 \mathrm{~B}$ and $2 \pm 1 \mathrm{kbar}$ for clinopyroxene from sill 260A (Neave and Putirka 2017).

Plagioclase is ubiquitous and was analyzed in 22 samples, with compositions ranging from $\mathrm{An}_{82}$ (bytownite) to nearly pure albite $\left(\mathrm{An}_{2}\right)$. Strong normal zoning is common. Compositions approaching pure albite are exclusively found at the rims, especially in crystals bordering late-stage micropegmatitic pockets. In contrast to what is observed for olivine and clinopyroxene, crystals from sample 260/3008.2 are normally zoned. K-feldspar was analyzed within the evolved interstitial pockets.

\section{Whole-rock geochemistry}

\section{Major elements}

Whole-rock major elements were anlayzed on 69 dolerites, 2 gabbroic enclaves and 4 sedimentary rocks (representative analyses in Table 1; complete dataset in Supplementary information 2). With $\mathrm{SiO}_{2}$ ranging between 47.56 and $53.09 \mathrm{wt} \%$ and total alkali $\left(\mathrm{Na}_{2} \mathrm{O}+\mathrm{K}_{2} \mathrm{O}\right)$ between 2.37 and $4.56 \mathrm{wt} \%$, most dolerites classify as basalts on a total alkali-silica (TAS) classification diagram (Fig. 3c; Le Maitre 2002), with four samples classifying as basaltic andesites. All but 5 dolerites are subalkaline, plotting at or below the alkaline/subalkaline separation curve (Irvine and Baragar 1971). Rocks from sills 219B, 219C, 219E, 277A and 277D depict trends of increasing alkali with increasing silica, whereas sills 260A, 260B and 275G show a negative correlation. Loss on Ignition (L.O.I.) for most rocks is low ( $<2 \mathrm{wt} \%$ ), with the exception of samples 260B-3004.9 (2.57 wt\%) and 275G/2634.2 (3.48 wt\%). L.O.I. increases with increasing $\mathrm{Na}_{2} \mathrm{O}$ and $\mathrm{K}_{2} \mathrm{O}$ concentration, but is not correlated with $\mathrm{CaO}$ content. The dolerites are mildly to strongly evolved basalts, with $\mathrm{MgO}$ from 3.68 to $9.60 \mathrm{wt} \%$, (most samples have $\mathrm{MgO}>5 \mathrm{wt} \%$ ), resulting in $\mathrm{Mg \#}$ from 64 to $34(\mathrm{Mg} \#=$ molar $100 \times[(\mathrm{MgO} / 40.3) /(\mathrm{MgO} / 40.3+($ $\left.\left.\mathrm{FeO}_{\text {tot }} \times 0.85 / 71.85\right)\right]$, assuming $\left.\mathrm{Fe}^{3+} / \mathrm{Fe}_{\text {tot }}=0.15\right)$. All the dolerites show low $\mathrm{TiO}_{2}(<2 \mathrm{wt} \%$; Fig. 3a), except two evolved samples from the upper portion of sill 277D and the melanocratic enclave. Dolerites from 260B have higher $\mathrm{TiO}_{2}$ than the other rocks for a given $\mathrm{MgO}$. $\mathrm{MgO}$ correlates negatively with $\mathrm{TiO}_{2}, \mathrm{Fe}_{2} \mathrm{O}_{3 \text { tot }}, \mathrm{P}_{2} \mathrm{O}_{5}$ and $\mathrm{SiO}_{2}$, and positively with $\mathrm{Al}_{2} \mathrm{O}_{3}$. CaO concentrations are too scattered to depict any trend (Fig. 3b; Fig.S4). The major element compositions of our dolerites fall within the field of previously published data for Siberian Traps sills (Fig. 3), and with the lavas of the Middle and Upper sequence (Fedorenko et al. 1996).

\section{Trace elements}

The TB dolerites show variable REE abundances $\left(\mathrm{La}_{\mathrm{CH}}=18-73, \mathrm{Yb}_{\mathrm{CH}}=12-31\right.$ times chondritic concentrations; McDonough and Sun 1995), mostly with smooth, gently sloped patterns broadly parallel with each other (Fig. 4; Fig. S5a-c). Most samples show $(\mathrm{La} / \mathrm{Yb})_{\mathrm{CH}}$ from 1.46 to $2.54,(\mathrm{La} / \mathrm{Sm})_{\mathrm{CH}}$ from 0.90 to 1.47 , and variable Eu anomalies (0.6-1.2; calculated as $\mathrm{Eu}^{*}=\mathrm{Eu}_{\mathrm{CH}} /\left(\mathrm{Sm}_{\mathrm{CH}} \times \mathrm{Gd}_{\mathrm{CH}}\right)^{\wedge} 0.5$; Supplementary information 2). Gabbroic, evolved rocks sampled at the top of sills 219B, 219E, 277D and 277E are the most enriched in REE (Fig. 4a-b), with mildly negative Eu anomalies 
Fig. 3 a) Whole-rock variation diagrams of $\mathrm{TiO}_{2}$ and $\mathrm{CaO}$ against $\mathrm{MgO}$. Plotted are also the 2 specimens from the coarse-grained enclave from sill 219D. Previously studied sills compositions are also shown, either as a compositional field (Hawkesworth et al. 1995; Egorova and Latypov 2013; Kiselev et al. 2014; Sibik et al. 2015; Krivolutskaya et al. 2020) or with data points (Usol'skii and Tolstomysovskii sills from Ivanov et al. 2008; sills of the Bratsk area from Black et al. 2012). Data by Egorova and Latypov (2013) extend to higher $\mathrm{MgO}$ than our dolerites (up to $12 \mathrm{wt} \% \mathrm{MgO}$ ), due to the cumulitic character of many of their samples. Symbols grow darker with increasing depth of the sills. A full set of major element variation diagrams is available in Supplementary information 1 (Fig. S4). Liquid lines of descent are calculated for $60 \%$ fractional crystallization after emplacement of the sills, starting from the most primitive dolerites with the Magma Chamber Simulator (Bohrson et al. 2020; Heinonen et al. 2020) at $1 \mathrm{kbar}$ at anhydrous and hydrous conditions. Fractionating phases for anhydrous conditions from 219/1410-15: 5\% ol, 30\% cpx, 25\% plg; from 260/2225-30, 30\% plg, 30\% cpx. Fractionating phases for hydrous onditions from 219/1410-15: 13\% ol, 22\% cpx, $23 \% \mathrm{plg}, 2 \%$ spinel; from 260/2225-30: $8 \%$ ol, $24 \% \mathrm{cpx}, 24 \% \mathrm{plg}$, $4 \%$ spinel. c) The analyzed dolerite samples (69) are plotted on a portion of the TAS classification diagram (Le Maitre 2002). Analyses are recalculated on a volatile-free basis. The dashed discriminating line for alkaline character is from Irvine and Baragar (1971). A mixing line between 260A dolerite and 10\% impure salt (Pang et al. 2013) is shown. Tick marks every $1 \%$ mixing

$(0.80-0.90)$. In sill 219D, the central samples and the gabbroic enclaves have the highest REE concentrations. Sills 260A and 260B show very uniform within-sill compositions, but 260B rocks are more enriched. Sill 277A1 marks a clear exception (Fig. 4b), with much higher LREE concentrations and higher LREE/HREE ratios, unlike all the other rocks analyzed (e.g. $\mathrm{La} / \mathrm{Sm}_{\mathrm{CH}}=1.82-2.09 ; \mathrm{La} / \mathrm{Yb}_{\mathrm{CH}}$ 3.84-4.12). Both portions of the enclave from sill 219D show the most enriched REE concentrations of the dataset and Eu negative anomalies (not shown).

Incompatible trace elements (ITE) normalized to the Primitive Mantle (Sun and McDonough 1989) show uniform patterns, with strong negative $\mathrm{Nb}$, and mild negative $\mathrm{Ti}$, Th and $\mathrm{P}$ anomalies, and with positive spikes in $\mathrm{Pb}(\mathrm{Pb}$ data available only for few samples) and $\mathrm{Sr}$ (Figs. 4c-d; $7 \mathrm{c}-\mathrm{d}$; S5a-c), i.e. typical arc-like signatures shared by many continental flood basalts (Wang et al. 2016; Pearce et al. 2021). The REE-enriched gabbroic evolved samples show a negative $\mathrm{Sr}$ spike and lack a negative $\mathrm{P}$ anomaly (Fig. 4d). This is accompanied by petrographic evidence for late crystallization of apatite in these rocks, mostly within the evolved late-stage pockets, with phosphorous (incompatible) being enriched in the most evolved melts. The dolerites from the 260 sills have very uniform ITE patterns, but samples of sill 260B never show a positive $\mathrm{Sr}$ anomaly (Fig. 7d). Sill 277/A1 shows higher abundance of the more incompatible elements and lower concentration of the least incompatible ones, with a pronounced negative Ti amonaly (Fig. 4d). The coarse-grained enclaves from
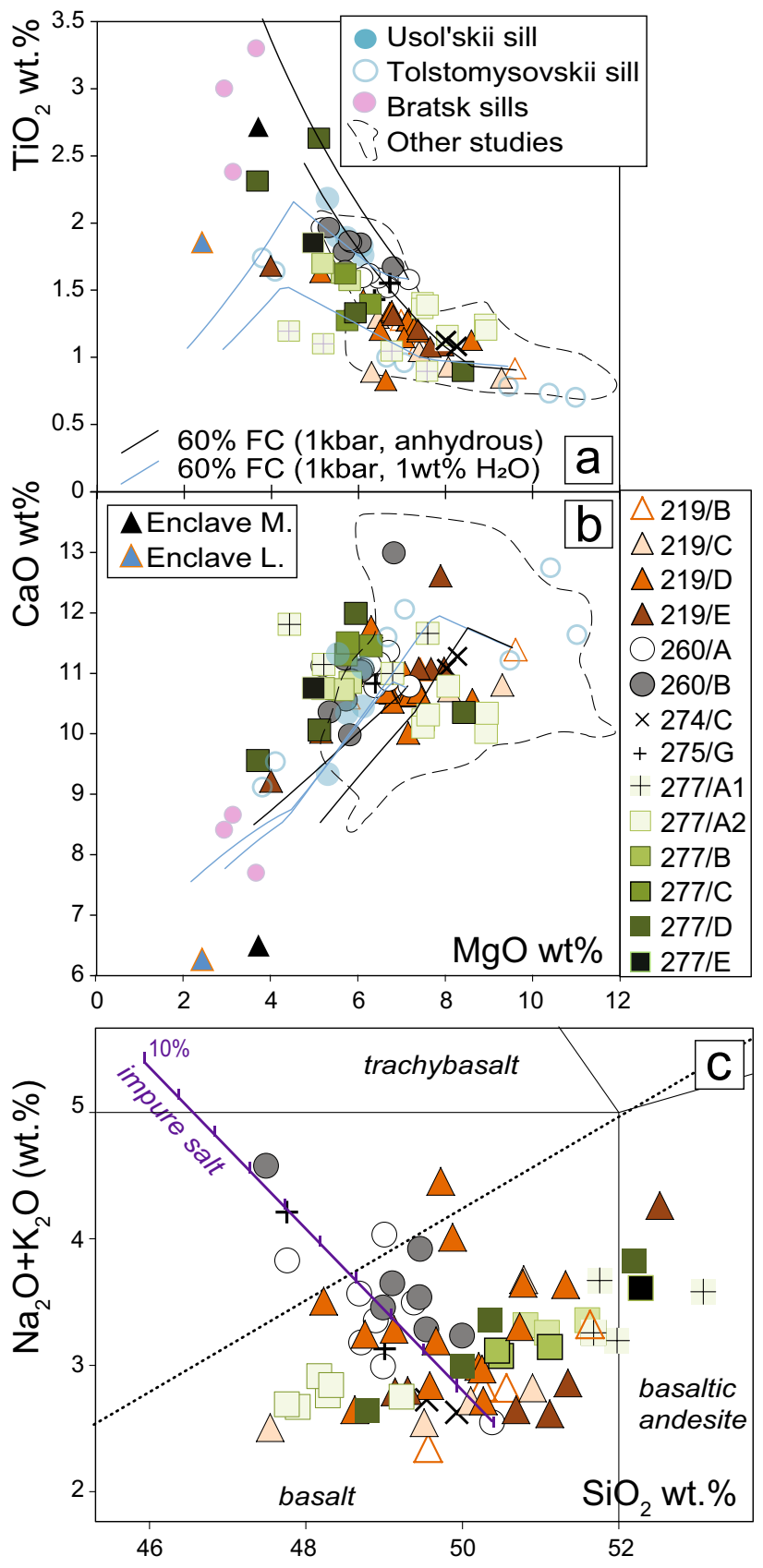

sill 219D show very enriched ITE patterns (particularly in $\mathrm{Zr}$, Hf and U; Fig. 4e). The leucocratic enclave is depleted in the mobile large-ion lithophile elements $\mathrm{Rb}, \mathrm{Ba}$ and $\mathrm{K}$ with respect to the melanocratic one, possibly as an effect of the observable hydrothermal alteration. The host rocks are variably enriched in $\mathrm{Sr}$ and $\mathrm{U}$, and depleted in $\mathrm{Nb}$ and Ti. Sample 260/2200 is enriched in K, whereas the halite-dominated sediment is depleted in K. ITE are strongly depleted in our evaporitic host rocks (Fig. 4e), as opposed to terrigenous lithologies (Pang et al. 2013; Sibik et al. 2015). 


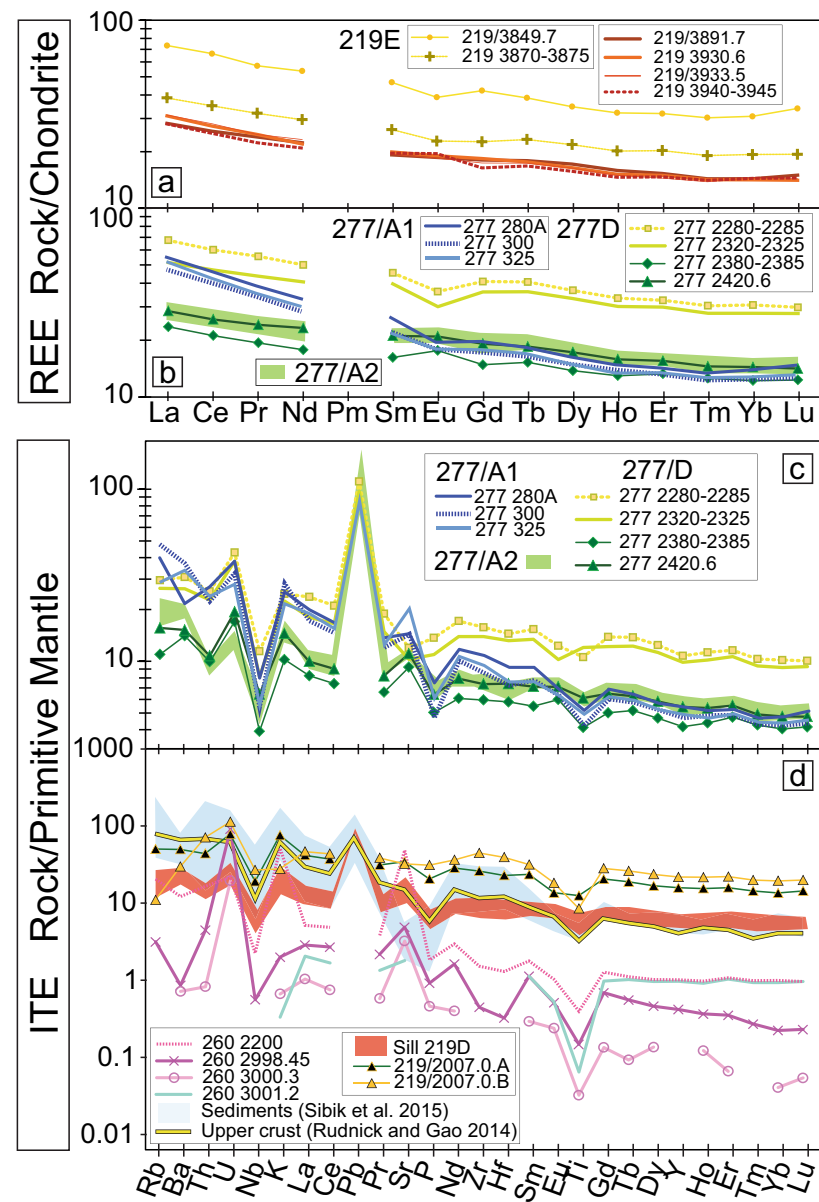

Fig. 4 Representative chondrite- and primitive mantle-normalized Rare-Earth Elements $(\mathbf{a}, \mathbf{b})$ and Incompatible Trace Elements (c, d) multi-element diagrams for the analyzed dolerites. The diagrams showing the full dataset are in Supplementary information 1 (Fig. S5a-c). The ITE compositional field of the sediments analyzed by Sibik et al. (2015) and the average composition of continental crust (Rudnick and Gao 2014) are shown in panel d) for comparison with the host rocks analyzed from borehole 260

\section{Isotopes}

Most dolerites form a cluster with ${ }^{87} \mathrm{Sr} /{ }^{86} \mathrm{Sr}_{\mathrm{i}}$ between 0.7048 and 0.7058 and ${ }^{143} \mathrm{Nd} /{ }^{144} \mathrm{Nd}_{\mathrm{i}}$ between 0.51242 and 0.51235 (Fig. 5), overlapping the compositional fields for Morongovsky-to-Samoedsky Formations (Upper sequence) and for dolerites and differentiated intrusions (Naldrett et al. 1992; Hawkesworth et al. 1995; Fedorenko et al. 1996). Samples from 260A show the most uncontaminated compositions $(0.70455$; 0.51244). Dolerites from sill 219B, the shallowest from borehole 219, are shifted to the lower ${ }^{143} \mathrm{Nd} /{ }^{144} \mathrm{Nd}_{\mathrm{i}}$ (0.51234) and ${ }^{87} \mathrm{Sr} /{ }^{86} \mathrm{Sr}_{\mathrm{i}}(0.7046)$ end of the cluster, overlapping with the Dolerites and differentiated intrusions field (type 3 from Naldrett et al. 1992). Sill 277A1 is isotopically very different, showing high radiogenic $\mathrm{Sr}$ coupled with low radiogenic $\mathrm{Nd}(277 / 300=0.70797-0.512024$ and
$277 / 325=0.708214-0.512048)$, similar in composition to the intrusions of Lower Talnakh-type, and approaching compositions of the Nadezhdinsky lava Fm. (Fig. 5a; Naldrett et al. 1992; Hawkesworth et al. 1995; Yao and Mungall 2021).

We observe two potential trends in the $\mathrm{Sr}-\mathrm{Nd}$ isotopic space. A steep trend towards low radiogenic ${ }^{143} \mathrm{Nd} /{ }^{144} \mathrm{Nd}_{i}$ and high radiogenic ${ }^{87} \mathrm{Sr} /{ }^{86} \mathrm{Sr}_{\mathrm{i}}$ is indicated by $277 \mathrm{~A} 1 \mathrm{sam}-$ ples. Conversely, four dolerites (from sills 219C, 219D and 277E) and the leucocratic enclave are shifted from the main cluster towards more radiogenic $\mathrm{Sr}$ isotope values at similar ${ }^{143} \mathrm{Nd} /{ }^{144} \mathrm{Nd}_{\mathrm{i}}$, forming a subhorizontal trend in $\mathrm{Sr}-\mathrm{Nd}$ space. Rocks of this latter trend overlap the compositions of Norilsk-type intrusive rocks (Fig. 5a; Hawkesworth et al. 1995; Arndt et al. 2003; Yao and Mungall 2021). Strontium concentration and ${ }^{87} \mathrm{Sr} /{ }^{86} \mathrm{Sr}$ signatures correlate positively (Fig. 5b). The data from single sills do not describe an isochron on a ${ }^{87} \mathrm{Rb} /{ }^{86} \mathrm{Sr}$ vs. ${ }^{87} \mathrm{Sr} /{ }^{86} \mathrm{Sr}$ plot, suggesting that the system was perturbed, potentially by late-stage hydrothermalism. No correlation is observed between ${ }^{87} \mathrm{Sr} /{ }^{86} \mathrm{Sr}$ and whole-rock $\mathrm{MgO}$, nor between Nd isotope signature and concentration (Fig.S6). The dolostone sample 260-2200 and the halite-anhydrite sample 260-3001.2 are fairly radiogenic in ${ }^{87} \mathrm{Sr} /{ }^{86} \mathrm{Sr}_{\mathrm{i}}(0.708755 ; 0.707792$, respectively). The first is enriched in $\mathrm{Sr}$ (1024 ppm), the latter is Sr-poor (38 ppm). These host rocks were not analyzed for $\mathrm{Nd}$ isotopes due to their low Nd concentration (4 ppm).

\section{Discussion}

\section{Geochemical correlations with STLIP chemostatigraphy}

We compare our data on the TB sills to previously studied rocks from the STLIP, proposing correlations between sills, formations and intrusive magma types (Figs. 6, 7 and 8 ). The correlation between subvolcanic rocks and lavas can be hindered by accumulation or fractionation of mineral phases. The mineral-whole rock disequilibrium suggests some accumulation of mafic phases in the TB dolerites (Fig. 3). However, unlike what oberved for cumulitic rocks from layered mafic intrusions, the TB dolerites do not show extreme depletions in trace element concentrations, and in most cases their major element compositions do not appear controlled by accumulation of some mineral phase (cf. the compositions of rocks from the Freetown Layered Complex; Callegaro et al. 2017; cf. also STLIP sills in Egorova and Latypov 2013). This is also supported by similarities in major and trace element concentrations between microporphyritic (chilled margin) samples, and holocrystalline ones in homogeneous sills (e.g. 260B). We stress however that the proposed correlations are mostly 


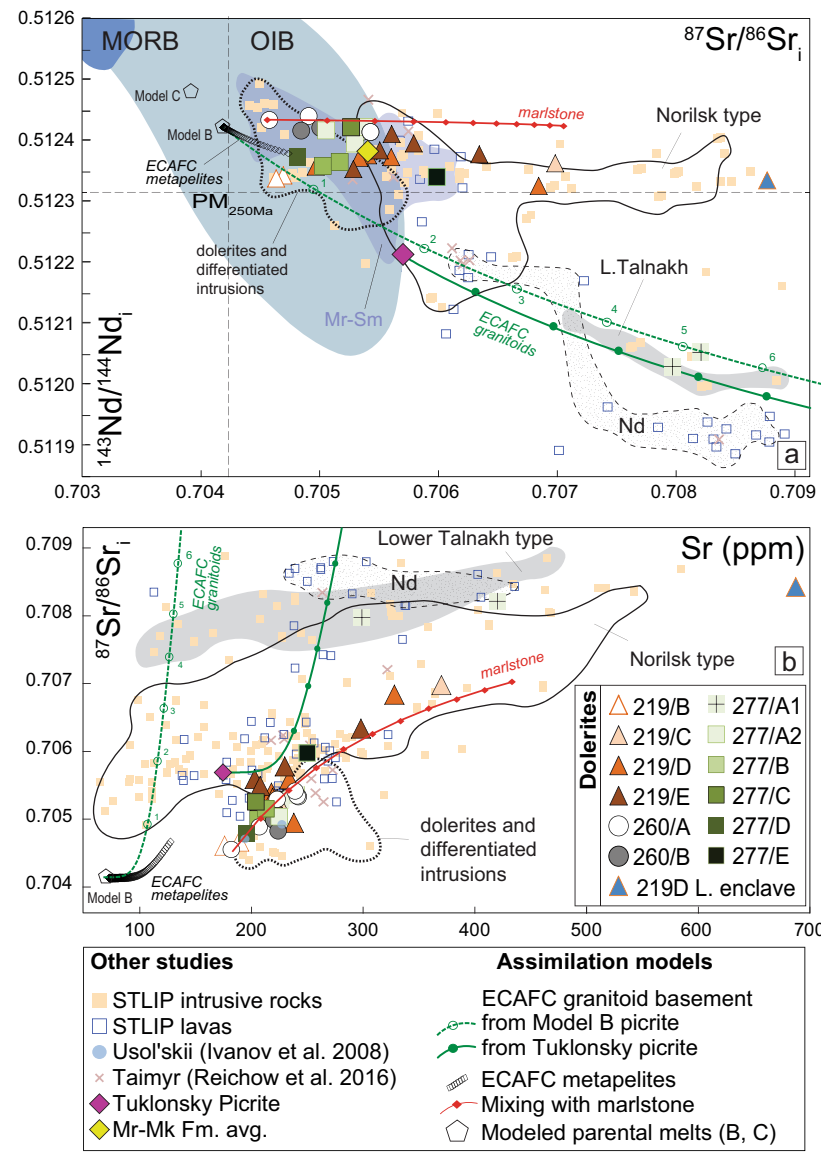

Fig. 5 a) $\mathrm{Sr}-\mathrm{Nd}$ isotope values and b) ${ }^{87} \mathrm{Sr} /{ }^{86} \mathrm{Sr}$ vs. $\mathrm{Sr}$ (ppm) of a subset of dolerites $(n=32)$ plus the leucocratic enclave 219/20070B. Isotopic values are corrected for radiogenic in-growth to $251 \mathrm{Ma}$, using trace element concentrations obtained by ICP-MS on the same aliquot sample. Compositional fields for the Nadezhdinsky (Nd) and Upper Sequence lava formations (Morongovsky to Samoedsky, $\mathrm{Mr}-\mathrm{Sm}$ ) and for the Norilsk and Lower Talnakh-type intrusions are from Naldrett et al. (1992), Hawkesworth et al. (1995), Fedorenko et al. (1996), and Sharma (1997). Previously published data from the cratonic STLIP are plotted for comparison (intrusive rocks from: Hawkesworth et al. 1995; Arndt et al. 2003; Ivanov et al. 2008; Kiselev et al. 2014; Krivolutskaya et al. 2020; Yao and Mungall 2021, and references therein; effusive rocks from: Lightfoot et al. 1990; Sharma et al. 1991; Sharma 1997; Wooden et al. 1993; Fedorenko et al. 1996; Krivolutskaya et al. 2020). Composition of intrusive and effusive rocks from Taimyr are also plotted (Reichow et al. 2016). Fields for OIB and MORB compositions are compiled from the GEOROC geochemical database (georoc.mpch-mainz.gwdg.de/georoc). ECAFC trajectories are calculated for i) upper crustal basement granitoids (gneiss and leucogranites; ${ }^{87} \mathrm{Sr}^{86} \mathrm{Sr}_{\mathrm{i}}=0.734 ; \mathrm{Sr}=280 \mathrm{ppm}$; ${ }^{143} \mathrm{Nd} /{ }^{144} \mathrm{Nd}_{\mathrm{i}}=0.5115 ; \mathrm{Nd}=16 \mathrm{ppm}$; Czamanske et al. 2000). Tick marks every $1 \%$; ii) upper crustal metapelites $\left({ }^{87} \mathrm{Sr}^{86} \mathrm{Sr}_{\mathrm{i}}=0.7091\right.$; $\mathrm{Sr}=233 \mathrm{ppm} ;{ }^{143} \mathrm{Nd} /{ }^{144} \mathrm{Nd}_{\mathrm{i}}=0.5123 ; \mathrm{Nd}=26 \mathrm{ppm} ;$ Czamanske et al. 2000; ECAFC path reaches $2 \%$ assimilation with $60 \%$ crystallization). Mixing line with marlstone (Pang et al. 2013) is calculated until $10 \%$ mixing, tick marks every $1 \%$. The parameters used for the ECAFC model are listed in Supplementary information 2. The compositions of these and other considered assimilants are shown in Supplementary Fig. S10 based on isotopes and REE ratios, that are nearly insensitive to fractionation or accumulation of a basaltic mineral assemblage. For instance, $50 \%$ fractional crystallization (FC) of $5 \%$ olivine, $30 \% \mathrm{cpx}, 25 \%$ plag from the most primitive of the dolerites at $1 \mathrm{kbar}$, anhydrous conditions calculated by the Magma Chamber Simulator (MCS; Bohrson et al. 2020; Heinonen et al. 2020), is negligible on the REE ratios used for correlations (FC path has the same dimension as the symbols used in Figs.6c and 7b).

None of the rocks in our dataset is alkaline or highTi (Fig. 3), confirming absence of alkaline STLIP products south of the Maymecha-Kotuy region and absence of high-Ti products south of the Kulyumber river (Krivolutskaya et al. 2020). A plot of ${ }^{87} \mathrm{Sr} /{ }^{86} \mathrm{Sr}_{\mathrm{i}}$ vs. $\Delta \mathrm{TiO}_{2}$ (Ivanov and Balyshev 2005; Fig. 6b) helps discriminate between sequences. Most samples fall in the Upper sequence compositional field, with only 5 samples in the Middle sequence field. However, in a plot of Th/U vs. Gd/ Yb (Fig. 6a), all the samples classify as Lower sequence, except for one dolerite from 277A1, showing affinity with the Middle sequence. REE ratios $(\mathrm{Gd} / \mathrm{Yb}$ and $\mathrm{Sm} / \mathrm{Yb}$ vs. $\mathrm{La} / \mathrm{Sm}$ ) and isotopes classify all three rocks from $277 \mathrm{~A} 1$ within the Nadezhdinsky Fm. and Lower Talnakh compositional fields (Figs.5a; 6c; 7b). Dolerites from all the other sills overlap with the Upper Sequence lava formations, from Morongovsky to Samoedsky ( $\mathrm{Mr}-\mathrm{Sm}$ in the Figures). Sills 219C-E, 274C and 277B-E correlate more specifically with the Morongovsky-Mokulaevsky Fm. and the Norilsk 5A intrusives. We note that samples from sill 219D overlap with the compositional field of Tuklonsky (Tk) formation in Fig. 6c, but correlation with this formation is excluded by the Th/U vs. Gd/Yb diagram (Fig. 6a), and by isotope data (Fig. 5a).

Correlations with intrusive types hinge on $\mathrm{Sr}-\mathrm{Nd}$ isotopes (note that no isotope analyses are available for 274 and 275 borheoles). Of the TB sills, 219B, 260A-B and 277B can be all classified as type 3 intrusives (dolerites and differentiated intrusions in Fig. 5a). Of these, 219B shows higher $\mathrm{Sm} / \mathrm{Yb}$, and lower $\mathrm{La} / \mathrm{Sm}$ and ${ }^{143} \mathrm{Nd} /{ }^{144} \mathrm{Nd}_{\mathrm{i}}$ at comparable ${ }^{87} \mathrm{Sr} /{ }^{86} \mathrm{Sr}_{\mathrm{i}}$ with respect to the other dolerites from the same borehole. These signatures are typical of the Ambarninsky type II dolerites that Hawkesworth et al. (1995) correlated with the Kharaelakhsky Formation (Hr in Fig. 1c). Sill 277A1 can be classified as a 5B-Lower Talnakh-type intrusive (Fig. 5a-b). All the remaining sills, 219C-E, 277B to E, following the suborizonthal Sr-enrichment trend, are classified as Norilsktype $5 \mathrm{~A}$ intrusions.

We stress that these sills belong to the STLIP event beyond reasonable doubt (Vasiliev et al. 2000; Svensen et al. 2018; Burgess and Bowring 2015). Older mafic rocks, such as thoe of the Viluy province (Kiselev et al. 2014) or the volcanics found as xenoliths in the Maslov diatreme (Czamanske et al. 2000), show very different geochemistry (e.g. 
alkaline affinity, more fractionated $\mathrm{La} / \mathrm{Yb}$, high $\mathrm{TiO}_{2}$ ). The TB dolerites plot within the field of the STLIP on the newly proposed classification diagram (LIP printing; Pearce et al. 2021; Fig. 8b). Some sills cropping out at the periphery of the $\mathrm{TB}$, or along valleys cutting trough it, show U-Pb ages well within the STLIP event (Burgess and Bowring 2015). The only potential exception is sill $260 \mathrm{~B}$, correlated with the Usol'skii sill (Ivanov et al. 2008), interpreted to be the youngest in the area and dated by ${ }^{40} \mathrm{Ar} /{ }^{39} \mathrm{Ar}$ to the Early Triassic (ca. 244 Ma; Ivanov et al. 2013), although U-Pb dating never showed such young ages (Burgess and Bowring 2015).

\section{Sill profiles and within-sill differentiation processes}

Compositional variations along profiles from tholeiitic sills can offer information into syn- and post-emplacement differentiation processes. We organized samples according to their level in the sill to allow identification of compositional profiles for compatible elements or differentiation indexes (i.e., $\mathrm{Mg} \#, \mathrm{CaO}, \mathrm{Ni}$, and $\mathrm{Cr}$ ). For the compositional profiles in Figs.S5-6 we refer to established nomenclature, i.e., I-, D-, S- and slash-shaped profiles (cf. Gibb and Henderson 1992; Latypov 2003; Galerne et al. 2010; Egorova and Latypov 2013), and those that did not fit in any established pattern are flagged as X-shaped profiles. The sampling density was not equal for each sill and in some case samples were not numerous enough to determine compositional profiles (e.g. for sills 277E, 274C and $275 \mathrm{G})$. Also, since we use borehole samples, we only have access to one profile from each sill, and cannot exclude the existence of different types of compositional profiles along the same sill (Galerne et al. 2010). D-shaped profiles, with the least-differentiated rocks at the center and more evolved margins, are visible for sills 219B (4 samples over 215 m thickness; Fig.S7a-b) and 219C (5 samples over $148 \mathrm{~m}$ ) and sill 277A1 (3 samples over min. $64 \mathrm{~m}$ ). Sills 277D (4 samples over $193 \mathrm{~m}$ ) and 219E (6 samples over $162 \mathrm{~m}$ ) show a slash-shaped profile (Fig. S7c, d), i.e. gradually more differentiated rocks from base to top. Top samples from these sills are enriched in REE (Fig. 4a, b), with mildly negative $\mathrm{Sr}$ and Eu anomalies (0.80-0.90), likely reflecting crystallization from an evolved melt that fractionated plagioclase. A typical S profile (highest $\mathrm{Mg \#}$ rocks at the top, followed by more evolved compositions) is shown by the thin sill 260B ( 7 samples over $97 \mathrm{~m}$ thickness; Fig. S7g, h). I-shaped profiles (uniform composition throughout the thickness) are visible for sills 277B (3 samples over $85 \mathrm{~m}$ ) and $277 \mathrm{C}$ ( 3 samples over $85 \mathrm{~m}$ ), although samples are available only from the upper half of these thin sills. Complex profiles (X-shaped) are shown by sills 219D (14 samples over 148 m; Fig. S7e, f), 260A (8 samples over $29 \mathrm{~m}$ ) and sill 277A2 (6 samples over $100 \mathrm{~m}$ ). The slash-shaped profiles in sill 277D (193 m) and 219E
(162 m) are typical of sills that developed cumulates from the bottom upwards, as a result of closed-system crystallization and gravity-driven crystal settling followed by compaction of the cumulate pile and subsequent extraction of the interstitial melt to upper levels. This is evidenced also by the REE and IE patterns of the samples from these sills (Fig. 4). For example, the composition of the evolved samples of sill 277D can be reached after $60 \%$ fractional crystallization in situ (5\% ol; $30 \% \mathrm{cpx} ; 25 \%$ plag) from a basalt (Fig. 3; liquid lines of descent modeled by MCS, starting from the composition of the most primitive dolerite in our dataset 219/1410-15). Incompatible trace elements are depleted in the bottom samples, and enriched at the top, as a result of the preferential partitioning of these elements into the melt during the early stages of crystallization. This is illustrated by $\mathrm{La} v \mathrm{La} / \mathrm{Yb}$ (Fig. 7a), where the evolved roofs and cumulitic floors of the slash-shaped sills 219E and 277D-E are tied by horizontal FC paths (i.e. $\mathrm{La} / \mathrm{Yb}$ is insensitive to $\mathrm{FC}$ ) calculated with MCS. Coherently, the $\mathrm{Eu} / \mathrm{Eu}^{*}$ and $\mathrm{Sr}$ negative anomalies in the coarsegrained evolved rocks from the top portions of these sills reflect crystallization after plagioclase fractionation. In sill 219E (Fig.S8), olivine is present in the bottom samples $(219 / 3930.6,3933.5$ and 3891.7) but not in the very coarse-grained, evolved top samples. Instead these show well-developed late-stage granophyric melt pockets (e.g. 219/3848.3). D-shaped profiles are visible only in relatively thick sills. These profiles may be the result of postemplacement melt flow from the central part of the sill to the top and bottom portions, induced by thermal stresses (Aarnes et al. 2008) or by uneven sill shape (Galerne et al. 2010). Relatively evolved melt (enriched in Fe and incompatible elements) flows towards the bottom and top of the sill, leaving behind a depleted high-Mg\# crystal mush rich in compatible elements. However, we do not have enough data to correlate this information with the textural analysis and mineral chemistry.

We may tentatively interpret the gabbroic enclave in sill 219D as an autolith (Figs. S2 and S8), a coarse-grained portion of the same magmatic body remobilized by convective flux (Sparks et al. 1984), activated during cooling, or after a new batch of hotter, more primitive melt entered the system. Alternatively, given its more evolved geochemistry, the enclave may be a pegmatitic segregation (e.g. Marsh 2002), albeit at an embryonic stage, although this would be at odds with the sharp contact with the fine-grained dolerite. Brecciated sedimentary (limestone/dolostones and halite/anhydrite) xenoliths of the host rock were also found within sill 219D (Fig. S2), and can be interpreted as rafts of host rocks enclosed in the magmatic body by stoping. Localized assimilation of these xenoliths may be responsible for the chaotic compositional profile (X-shape) seen for this sill (Fig. S7e, 

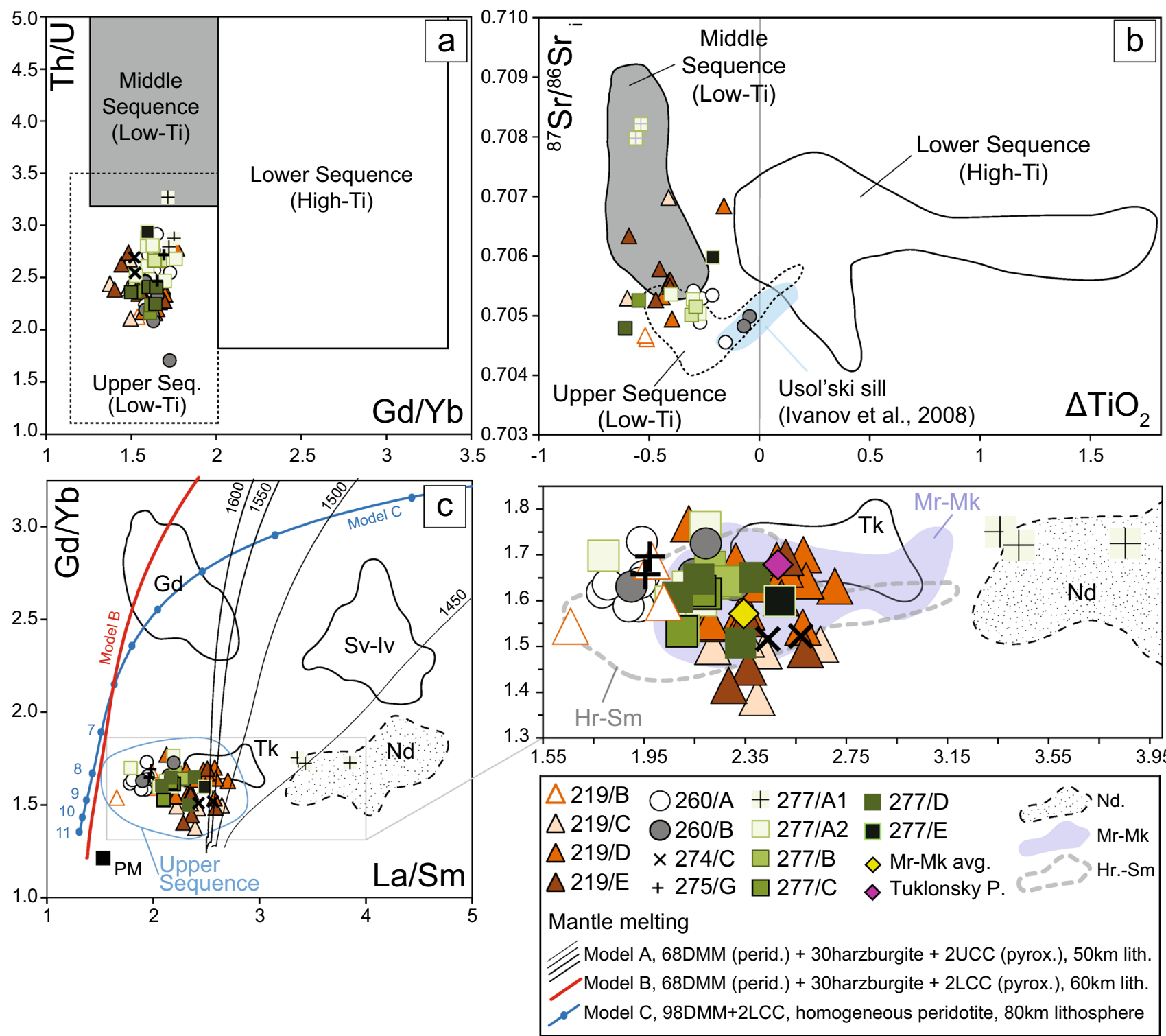

Fig. 6 Classification diagrams for STLIP lava Sequences based on a $\mathrm{Th} / \mathrm{U}$ and $\mathrm{Gd} / \mathrm{Yb}$ ratios (Fedorenko et al. 1996; Ivanov et al. 2008); b ${ }^{87} \mathrm{Sr} /{ }^{86} \mathrm{Sr}_{\mathrm{i}}$ vs. $\Delta \mathrm{TiO}_{2}$, defined as demarcation line between high- and low $\mathrm{TiO} 2$ (line equation is: $\mathrm{TiO}_{2}=3.45-0.0317 \times \mathrm{Mg}$, where $\mathrm{Mg} \#$ is $\mathrm{Mg} /\left(\mathrm{Mg}+0.85 \mathrm{Fe}_{\text {tot }}\right)$; elements in atomic units; Ivanov and Balyshev (2005); c Gd/Yb vs. La/Sm (Lightfoot et al. 1993; Hawkesworth et al.
1995) and enlarged inset. The effect of $60 \%$ FC (mineral assemblage of $5 \%$ ol; $30 \% \mathrm{cpx} ; 25 \%$ plag) calculated at $1 \mathrm{kbar}$, anhydrous conditions by MCS (Bohrson et al. 2020; Heinonen et al. 2020) is negligible on REE ratios (calculated vector is smaller than symbols). Model mantle melting curves A, B and C are plotted in panel c

describes a near-horizontal trend, unable to reproduce all the spread in $\mathrm{La} / \mathrm{Yb}$ covered by the data. The differences in $\mathrm{La} / \mathrm{Yb}$ can reflect different parental melts or crustal assimilation, as backed up also by positive trends between $\mathrm{La} / \mathrm{Yb}$ or $\mathrm{La} / \mathrm{Sm}$ and $\mathrm{La}$. The high $\mathrm{Th} / \mathrm{Nb}$ (from 0.16 to 0.51 ) compared to mantle-derived melts (e.g. MORB 0.053; Sun and McDonough 1989; cf. Figure 8a) shown by all the dolerites also suggests some crustal contribution.

In summary, closed-system differentiation processes can explain the within-sill variability in major and trace element 

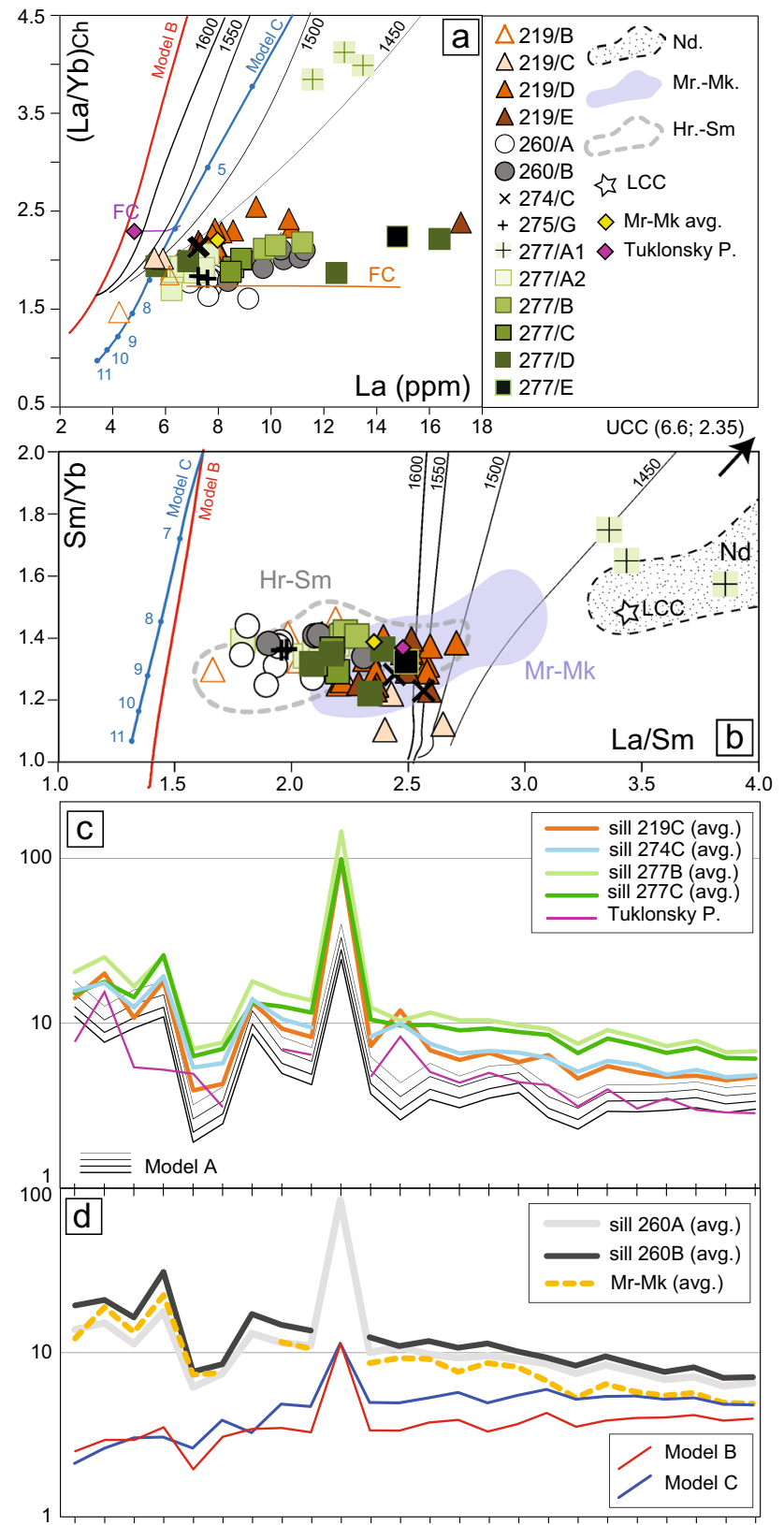

$\mathrm{Rb}$ Ba Th U Nb Ta K La CePb Pr Sr NdSm Zr Hf Eu Ti Gd Dy Y Er Yb Lu

Fig. 7 a Within-sill fractional crystallization (FC) path (orange) calculated starting from sample 219/1410-15, was calculated with the MCS (Bohrson et al. 2020; Heinonen et al. 2020). The curve represents $60 \%$ fractional crystallization (5\% ol; 30\% cpx; $25 \% \mathrm{plag}$ ) from a basalt, shown also in Fig. 3 for major elements. The FC is calculated at $1 \mathrm{kbar}$ at anhydrous conditions. Purple line starting from Tuklonsky picrite composition (Yao and Mungall 2021) marks the trajectory for FC of $16 \%$ olivine, $2 \%$ spinel and $7 \%$ clinopyroxene from a picritic melt, at $3 \mathrm{kbar}$, anhydrous conditions. Partition coefficients for the FC paths are from Bédard (2014). b Mantle melting curves (also plotted in panels a and $\mathbf{c}$ are calculated with the REEBOX PRO software (Brown and Lesher 2016). The full parameters used for the models are listed in Supplementary information 2. Tick marks are placed every $1 \%$ melting for curve C. Compositional fields for the STLIP lava formations in $\mathbf{c}$ are built from data from Lightfoot et al. (1990, 1993); Wooden et al. (1993); Hawkesworth et al. (1995) concentrations. Instead, the differences in isotopes and REE ratios between different sills and in some case within the same sill need to be explained by other processes, such as different parental melts or open-system differentation. There is evidence for open-system evolution in some of the sills, e.g. (i) inverse zoning in some minerals suggesting injection of more primitive magma; (ii) autoliths suggesting turbulence created by injection of a new batch of magma; (iii) xenoliths within the sills (e.g. 219D); (iv) isotopic evidence of late-stage interaction with the evaporite-host rocks; (v) textures and mineralogical assemblages developed by magma-evaporite interaction at the contacts.

\section{Constraints on the mantle source of the TB dolerites}

We can try to deconvolve the effects of mantle melting, fractional crystallization (closed-system evolution) and crustal assimilation (open-system evolution) by analysis of the trace element and isotope features of the TB dolerites, although a precise reconstruction of their parental melts and of their mantle source is hindered by their fractionated (Mg\# 63-34; $\mathrm{Ni}<180 \mathrm{ppm})$ and contaminated $(\mathrm{Th} / \mathrm{Nb}>0.16)$ nature. Most TB dolerites geochemically resemble the lavas of the Upper sequence (Morongovsky to Samoedsky; hereinafter $\mathrm{Mr}-\mathrm{Sm}$ ) and the Norilsk-type 5A intrusive rocks. The dolerites from sill 277A1 are geochemically similar to the lavas of the Nadezhdinsky Fm and to the Lower Talnakh intrusives. Fedorenko et al. (1996) distinguished four primitive magma types in the classical Norilsk lava piles, among which the Tuklonsky picrites and the Upper sequence basalts. Due to their very uniform geochemistry and their positive $\varepsilon \mathrm{Nd}$ signatures, and the absence of picrites in this suite, they interpreted the Upper sequence $(\mathrm{Mr}-\mathrm{Sm})$ basalts as primitive mantle-derived melts. However, we favor the interpretation that the TB dolerites reflect various levels of differentiation from a picritic parental melt. A forward calculation using the MCS shows that it is possible to obtain the major element composition of the most primitive dolerites by fractionating $16 \%$ olivine, $2 \%$ spinel and $7 \%$ clinopyroxene from a picritic melt (Fedorenko et al. 1996). This is in agreement with the observation that $\mathrm{Ni}$ contents between 130 and 200 ppm can be derived by $15 \%$ FC of olivine from a mantle-derived primitive magma with 300-450 ppm Ni (Sharma 1997). Indeed, the positive correlation between $\mathrm{MgO}$ and $\mathrm{Ni}$ (not shown) suggests some control of olivine on these rocks. However, an attempt of reconstructing a primitive melt by addition of olivine to the TB dolerites with the PRIMELT3 MEGA software (Herzberg and Asimow 2015) failed because even the more primitive dolerites $(\mathrm{MgO}>8 \mathrm{wt} \%)$ were flagged as having fractionated clinopyroxene. The TB dolerites are thus moderately evolved melts derived from a parental picrite, but both the trace element and the isotope chemistry discard the Tuklonsky picrite as a 
Fig. 8 a REEBOX PRO curves are plotted on $\mathrm{T} \mathrm{Th} / \mathrm{Yb}$ vs $\mathrm{Nb} /$ Yb diagram. Mixing curves with the average UCC (Rudnick and Gao 2014) is also plotted. Tick marks every $5 \%$. In $\mathbf{b}$ the dolerite compositions are plotted on the newly proposed LIPprinting discrimination diagram of Pearce et al. (2021). Both diagrams show the concurrence of a depleted (MORB-like) component, and an enriched (crustal-like) component in the pretrogenesis of these dolerites
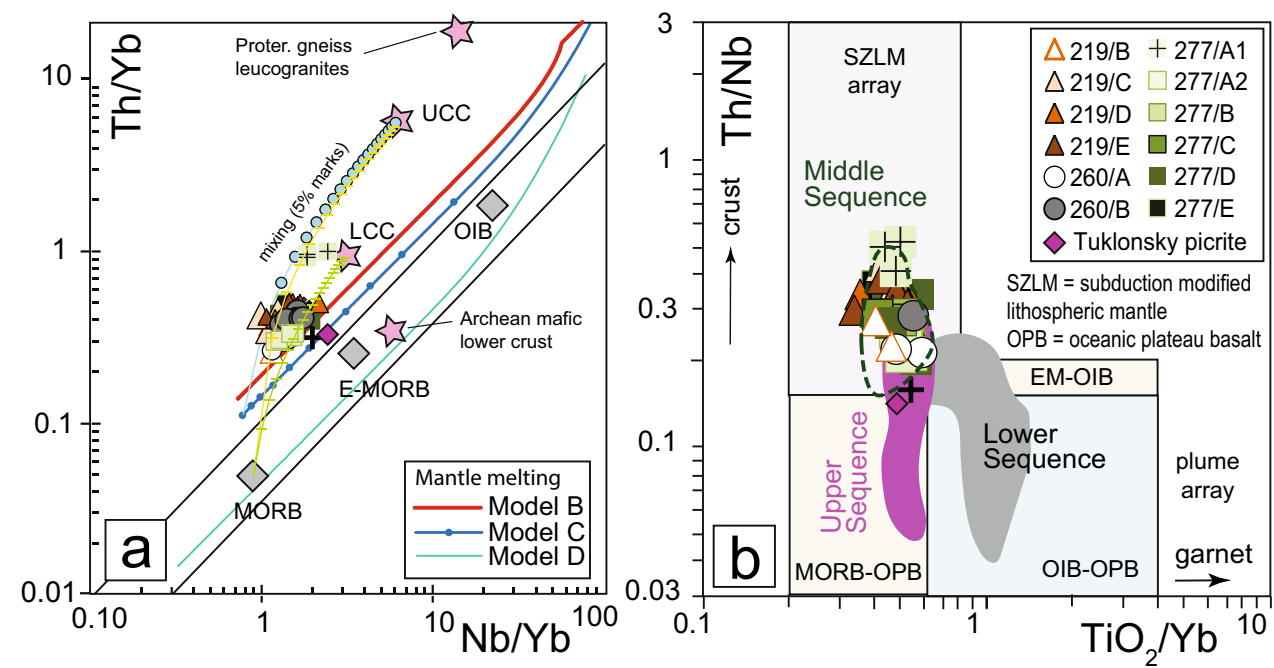

viable parental melt for most of the TB dolerites. Tuklonsky picrites have too high $\mathrm{La} / \mathrm{Yb}$ ratios and are isotopically too enriched (Figs. 5a and 7a, b) to represent the parental melts of the Upper sequence-like TB dolerites. On the contrary, Tuklonsky picrites can be related to the 277A1 dolerites by crustal contamination (as suggested previously for Nd-like basalts by, e.g. Wooden et al. 1993; Fedorenko et al. 1996; Reichow et al. 2005; Yao and Mungall 2021).

None of the analyzed dolerites show the characteristic highly fractionated LREE/HREE (e.g. La/Yb $>6$ ) or MREE/ HREE (e.g. Gd/Yb $>2$ ) indicative of low degree and deep $(>120 \mathrm{~km})$ mantle melting shown by the Lower sequence high-Ti basalts and picrites (Sobolev et al. 2009a, 2011). All the analyzed rocks show typical arc-like signatures, such as high LILE concentration and negative $\mathrm{Nb}$ and $\mathrm{Ti}$ anomalies (Fig. 4), in stark contrast with melts typically derived from primitive mantle sources (e.g. OIBs). For instance, they show low Nb/Y and Zr/Y (Fig.S9), below the so-called (Icelandic) mantle plume array (Fitton et al. 1997), overlapping with depleted, MORB-like compositions or with continental flood basalts from the Nb-depleted southern Karoo LIP (high percentage melts of a subduction-modified mantle source; Luttinen 2018; Fig.S9). We stress that Nb depletion can reflect either a $\mathrm{Nb}$-depleted mantle source or crustal contamination (Luttinen 2018). Indeed, these arc-like features were observed before in the Upper series lavas, and were interpreted in contrasting ways. Some authors reconized this as a source-related character (recycling of crust in the mantle source, Lightfoot et al. 1993; melting of the lithosphere, Hawkesworth et al. 1995; Fedorenko et al. 1996; melting of a hydrous, subduction-modified mantle source; Ivanov 2007; Ivanov et al. 2008; Wang et al. 2016). Others interpreted this character as reflecting evolution of mantle-derived melts in long-staging reservoirs at the base of the crust, where constant replenishment and assimilation could occur (Wooden et al. 1993; Arndt et al. 2003). More recently, Sobolev et al.
(2011) partially reconciled these views by suggesting a) that the source of the main tholeiitic phase magmas of the STLIP contained up to $50 \mathrm{wt} \%$ pyroxenite derived from reaction of recycled oceanic crust in the mantle plume with the peridotitic lithosphere, b) that melting occurred at shallow levels $(<60 \mathrm{~km})$, and c) that the resulting melts were strongly contaminated by the continental crust. We try to evaluate these models based on the evidence offered by the TB dolerites.

The most uncontaminated dolerites in our dataset show higher ${ }^{143} \mathrm{Nd} /{ }^{144} \mathrm{Nd}_{\mathrm{i}}$ than the primitive mantle recalculated to $250 \mathrm{Ma}$ (Reichow et al. 2016), arguing for a more depleted asthenospheric component (DMM-like) in their mantle source. This is well represented by the signatures of the Lower Sequence basalts $\left({ }^{87} \mathrm{Sr} /{ }^{86} \mathrm{Sr}_{\mathrm{i}} 0.7028 ;{ }^{143} \mathrm{Nd} /{ }^{144} \mathrm{Nd}_{\mathrm{i}}\right.$ 0.512755; Sharma 1997). Conversely, the relatively radiogenic ${ }^{87} \mathrm{Sr} /{ }^{86} \mathrm{Sr}_{\mathrm{i}}$ signatures point toward an enriched (crustallike) component.

Forward partial melting models were calculated with REEBOX PRO (Brown and Lesher 2016). We simulated melting of a mantle source with mixed peridotitic and pyroxenitic lithologies (Sobolev et al. 2011) where the pyroxenites represent recycled (continental and oceanic) crustal domains in the mantle. Model A (Fig. 7a-c): melting of a source with multiple lithologies, i.e. $68 \%$ peridotite with trace element composition of the depleted MORB mantle, DMM (Workman and Hart 2005); $2 \%$ pyroxenitic component representing recycled continental upper crust (MIX1G; trace element compositions of UCC as in Rudnick and Gao 2014); $30 \%$ harzburgite that does not reach melting, representing a lithological scenario compatible with the thermal destabilization of the cratonic lithosphere below Siberia described by Sobolev et al. (2011). Decompressional melting of this mantle source was modeled considering a pre-existing lithospheric thickness of $50 \mathrm{~km}$ (Sobolev et al. 2011) and mantle potential temperatures (Tp) from 1450 to $1600{ }^{\circ} \mathrm{C}$. We set a columnar shape for the melting region because more 
suitable for axial upwelling in mantle plumes or the rupture or foundering of thick, continental lithosphere (Tegner et al. 2019). Most dolerites from 219 and 277 boreholes are best represented by melting at the highest $\mathrm{Tp}$, with a final pooled melt composed by ca. $10 \%$ pyroxenitic (the pyroxenite melts completely) and ca. $90 \%$ peridotitic melt (the peridotite melts up to $27 \%$ ). The last melting occurs at ca. $2 \mathrm{GPa}$, within the spinel stability field. This melting model results in a picrite that already bears the characteristic arc-like trace element pattern shown by the dolerites (Nb-Ta and Ti through, $\mathrm{Pb}$ spike), except for $\mathrm{Rb}, \mathrm{Ba}$ and $\mathrm{Sr}$ (Fig. 7c). Assimilation of the TB sediments or circulation of late-stage fluids can reconcile these discrepancies in mobile elements. We note that similar results (not shown) are obtained by melting in the same T-P conditions a lithologically homogeneous mantle source ( $100 \%$ peridotite) in which $2-3 \%$ upper crust is recycled and well homogeneized (following the approach suggested by Tegner et al. 2019 for mantle source modeling of LIP-related tholeiites showing arc-signatures). However, dolerites from the borehole 260 show too low $\mathrm{La} / \mathrm{Sm}$ ratios to be produced by this melting scenario. More importantly, recycling of upper continental crust in the mantle source is discarded on isotopic basis. We cannot know the precise isotopic composition of the recycled crustal component, but even recycling a moderately radiogenic upper continental crust (e.g. ${ }^{87} \mathrm{Sr}^{86} \mathrm{Sr}_{\mathrm{i}} 0.710 ;{ }^{143} \mathrm{Nd} /{ }^{144} \mathrm{Nd}_{\mathrm{i}} 0.5116$ ), the mantle melts obtained are too isotopically enriched to represent the TB dolerites. If there is a recycled crustal component in the mantle source, this could have been a lower crustal component with low radiogenic signatures (akin to some lower crustal granulite xenoliths found in Udachnaya; e.g. ${ }^{87} \mathrm{Sr}^{86} \mathrm{Sr}_{\mathrm{i}} 0.70570 ; \mathrm{Sr}=235 \mathrm{ppm} ;{ }^{143} \mathrm{Nd} /{ }^{144} \mathrm{Nd}_{\mathrm{i}} 0.5120$; $\mathrm{Nd}=14.3$ ppm; Koreshkova et al. 2011).

Model B: A likely parental melt for most TB dolerites is obtained by melting similar lithologies $\left(\mathrm{Tp}\right.$ of $1500{ }^{\circ} \mathrm{C}$, pre-existing lithosphere of $60 \mathrm{~km}$ ) in which the pyroxenitic component has lower crustal characteristics. In this case the melting path ends at $2.08 \mathrm{GPa}$, producing a pooled picritic melt composed by $91 \%$ peridotite-derived melt (maximum melting degree of $18 \%$ ) and by $9 \%$ pyroxenite-derived melt (maximum melting degree of 63\%), and a relatively low radiogenic isotopic signature $\left({ }^{87} \mathrm{Sr} /{ }^{86} \mathrm{Sr}_{\mathrm{i}}\right.$ $0.7041 ;{ }^{143} \mathrm{Nd} /{ }^{144} \mathrm{Nd}_{\mathrm{i}} 0.51242$ ). The fraction of pyroxenitederived melt agrees with independent estimations based on trace element in olivine in Upper sequence lavas ( $\max$ 50\%; Sobolev et al. 2011).

Model C: A plausible parental melt for TB dolerites from 260 borehole is produced by $11 \%$ melting of a uniform peridotitic mantle source (DMM trace elements; Workman and Hart 2005; Tp $1500{ }^{\circ} \mathrm{C}$; preexisting lithosphere $80 \mathrm{~km}$ ) enriched by $2 \%$ recycled lower crust. The produced melt has isotopic signatures $\left({ }^{87} \mathrm{Sr} /{ }^{86} \mathrm{Sr}_{\mathrm{i}} 0.7039 ;{ }^{143} \mathrm{Nd} /{ }^{144} \mathrm{Nd}_{\mathrm{i}} 0.51248\right)$ compatible with the 260A-B sills, and the slighlty thicker lithosphere can be explained by a farther south position of the borehole. We note that mafic lower crust (Archean tholeiitic protholiths granulitized in the Proterozoic, as shown by xenoliths sampled by the Udachnaya kimberlite), could have plausibly foundered or delaminated during early interaction of the STLIP plume whith the lithosphere. Alternatively, Czamanske et al. (2000) suggested that subduction/ underthrusting of an accretionary block with mafic volcanics could have occurred shortly before the STLIP event under the western edge of the Siberian platform, and this material could enrich the Siberian sublithospheric mantle.

Caveat: this is a forward model, and the chosen parameters are plausible, but arbitrary, i.e. different combinations of parameters might lead to similar results, and we do not have strong constraints on the isotopic flavors of the recycled components. Furthermore, as exemplified in Fig. 8a (Th/ $\mathrm{Yb}$ vs. $\mathrm{Nb} / \mathrm{Yb}$ ), the dolerite trace element patterns can be interpreted as reflecting crustal enrichment in the mantle source (cf. mantle melting curves obtained by REEBOX PRO modeling), or crustal assimilation by parental melt produced by a depleted mantle (cf. mixing curves with UCC and local gneissic and leucogranitic Proterozoic basement; Czamanske et al. 2000), i.e. it is difficult to deconvolve the effects of mantle vs. crustal enrichment. However, in summary, considering these dolerites as parental mantle melts from a sublithosheric mantle enriched with recycled upper crust (model A), as suggested by Fedorenko et al. (1996) or Lightfoot et al. (1993) for the correlative Upper Sequence lavas would result in the best match for the trace element patterns, but would require (a) probably unreasonably isotopic depleted signatures for the recycled upper crustal component and (b) unreasonably low- $\mathrm{MgO}$ contents for picrititc melts produced at the modeled $\mathrm{Tp}$ and $\mathrm{P}$ conditions. The TB dolerites have fractionated olivine and clinopyroxene, as seen from attempts to reconstruct their primitive melt with the PRIMELT3 software and from MCS calculations. Rather, TB dolerites were more plausibly derived from picritic parental melts that fractionated to basalts by ponding in crustal magma chambers. It is also likely that they assimilated some crust in this context (see below), unless they fractionated below the lower crust (cf. Heinonen et al. 2016). Estimated pressures of crystallization of clinopyroxenes for Middle and Upper sequence rocks reveal crystallization at $<20 \mathrm{~km}$ depth, i.e. within the upper crust (Yao and Mungall 2021; Suvorov et al. 2006). Clinopyroxenes from sill 260B are an exception, as they reveal crystallization pressures up to $8 \mathrm{kbar}$ (Neave and Putirka 2017). We hence favor a model that explains the arc-like signatures of the TB dolerites partly as inherited from recycled lower crust (Model $\mathrm{B}-\mathrm{C})$ present in the mantle source in the form of pyroxenites (Sobolev et al. 2011), and partly as acquired by assimilation of the crust (Wooden et al. 1993; Arndt et al. 2003). Alternatively, the parental melts of the TB dolerites could 
derive from a depleted asthenosphere (DMM-like, with the isotopic flavor of the Lower Sequence rocks; Sharma 1997; Model $D$ ), acquiring their crustal-like trace elements only by assimilation en-route to the surface. We find this interpretation less likely because (a) it would not explain the high percentage of pyroxenite-derived melts calculated by Sobolev et al. (2011); (b) in such case one would expect to see STLIP products with compositions in between the more isotopically depleted Lower Sequence and the more enriched Middle and Upper Sequences; and (c) this scenario would require higher percentages of assimilated crust, which are not favored by the moderately radiogenic ${ }^{187} \mathrm{Os} /{ }^{188} \mathrm{Os}$ signatures found in the STLIP main tholeiitic series (Horan et al. 1995). We also note from modeling attempts that adding even small amounts of water to the mantle source (100-200 ppm) results in produced melt compositions that do not fit our data (e.g. more fractionated MREE/HREE), hence the common presence of biotite in these rocks is more indicative of water input from interaction with the sedimentary host rocks, such as marlstones (Pang et al. 2013), rather than a hydrous mantle source (cf. Ivanov et al. 2008; Wang et al. 2016; Ware et al. 2018)

\section{Crustal interaction: two different processes, two diverging isotopic trends}

Trace element and isotopic geochemistry of sills from the Lower Tunguska show that they experienced some degree of crustal contamination. In $\mathrm{Sr}-\mathrm{Nd}$ isotopic space, two trends are suggested by some of our data, and they are further supported by previously published data (Fig. 5a). Some samples from borehole 219 and 277 describe a trend towards higher radiogenic ${ }^{87} \mathrm{Sr} /{ }^{86} \mathrm{Sr}_{\mathrm{i}}$ at nearly constant ${ }^{143} \mathrm{Nd} /{ }^{144} \mathrm{Nd}_{\mathrm{i}}$, with respect to the main data cluster. The leucocratic enclave 219D/2007.0B plots to the Sr-radiogenic end of this trend (Fig. 5a). Norilsk-type STLIP intrusives (Naldrett et al. 1992; Hawkesworth et al. 1995; Arndt et al. 2003; Yao and Mungall 2021), some lavas of the Upper Sequence (from Morongovsky to Samoedsky Formations), and one of the Kulyumber dolerites (Krivolutskaya et al. 2020) also plot along this trend. Conversely, no rocks from Taimyr (Reichow et al. 2016) follow it.

A different trend, towards high radiogenic ${ }^{87} \mathrm{Sr} /{ }^{86} \mathrm{Sr}_{\mathrm{i}}$ and low radiogenic ${ }^{143} \mathrm{Nd} /{ }^{144} \mathrm{Nd}_{i}$, is indicated by the dolerites from 277A1 (Fig. 5a). Lower Talnakh-type intrusions, lavas of the Nadezhdinsky Fm. and some dolerites from the Taimyr region show similar isotopic compositions (Hawkesworth et al. 1995; Arndt et al. 2003; Reichow et al. 2016; Yao and Mungall 2021). A few data from the literature plot in an intermediate position between more isotopically depleted samples and the 277A1 dolerites, allowing for complete "sampling" of the trend (Hawkesworth et al. 1995; Kiselev et al. 2014; Reichow et al. 2016). We note that intrusive rocks from the Kulyumber river area, south of Norilsk (Figs.1a and 5a; Krivolutskaya et al. 2020) also fall on a steep trend in $\mathrm{Sr}-\mathrm{Nd}$ space, but with a different slope with respect to the one shown by the dolerites studied here. These two isotopic trends suggest involvement of at least two different contaminants and/or processes, one that is able to change both $\mathrm{Sr}$ and $\mathrm{Nd}$ isotopic signatures (steep trend), and one that is actively swaying $\mathrm{Sr}$ isotopes and concentrations, but is ineffective on the Nd isotopic system (sub-horizontal trend).

\section{Contamination with granitoids and metapelites in upper crustal magma chambers}

Forward mantle melting modeling reveals that part of the enriched trace element and isotopic signatures in the TB dolerites can be imparted directly by their mantle source, which included recycled lower crust. However, assimilation in crustal reservoirs appears to play an additional role, a scenario favored also by previous authors (Wooden et al. 1993; Arndt et al. 2003; Reichow et al. 2005, 2016; Yao and Mungall 2021). Specifically, addition of radiogenic Sr and LILE to the modeled parental melts is required. We start from the composition of the melts obtained by the REEBOX PRO calculations (Models B and C), and estimate crustal assimilation by Energy Constrained Assimilation and Fractional Crystallisation modeling (EC-AFC; Spera and Bohrson 2001; Heinonen et al. 2021; full parameters are given in the Supplementary information 2). As evidenced from geobarometry on clinopyroxenes in correlative STLIP lava flows of the Upper and Middle sequence (Yao and Mungall 2021), the magma reservoirs were located in the upper crust (5-20 km depth; Suvorov et al. 2006). The basement below the Tunguska Basin is sampled by the Maslov diatreme, $25 \mathrm{~km}$ south of Norilsk (Czamanske et al. 2000), which transported xenoliths of Proterozoic basement granitoids (gneiss, leucogranites, minor trondjemites) and metapelites. There is variability in isotopic compositions for the silicic rocks, but they all show very high radiogenic ${ }^{87} \mathrm{Sr}^{86} \mathrm{Sr}_{251 \mathrm{Ma}}$ $(>0.720)$ and low radiogenic ${ }^{143} \mathrm{Nd} /{ }^{144} \mathrm{Nd}_{251 \mathrm{Ma}}(<0.5118)$. We modeled contamination using available compositions of gneiss and leucogranites, and metapelites (Czamanske et al. 2000). This composition is reasonably representative of the Siberian craton upper crust, given that similar lithologies crop out also further SE in the Aldan shield where the Archean and Proterozoic basement is exposed (Jahn et al. 1998). Very minor assimilation of this upper crustal lithologies allows reproducing the main cluster of TB dolerites isotopic signatures (Fig. 5a). In particular, 1\% assimilation of granitoids with $50 \%$ crystallization, can reproduce the isotopic signature of sill 219B, whereas $2 \%$ assimilation of metapelites with $60 \%$ crystallization can reproduce the $\mathrm{Nd}$ systematics in the dolerites (Fig.S6). The evolved isotopic 
signatures of 277A1 rocks (i.e. low radiogenic ${ }^{143} \mathrm{Nd} /{ }^{144} \mathrm{Nd}_{i}$ and relatively high radiogenic ${ }^{87} \mathrm{Sr}^{86} \mathrm{Sr}_{\mathrm{i}}$ ) are reproduced by $5 \%$ assimilation of granitoids with $65 \%$ crystallization. The same signatures are seen in the Nadezhdinsky formation (Fedorenko et al. 1996), in the Lower Talnakh group intrusives (Hawkesworth et al. 1995; Arndt et al. 2003), in the West Siberian Basin basalts (Reichow et al. 2005) and in Taimyr (Reichow et al. 2016). Different plausible contaminants were suggested to explain these signatures, e.g. tonalitic upper crust (Lightfoot et al. 1990); the Bolgokhtokh granodiorite (Lightfoot et al. 1993; Wooden et al. 1993; Hawkesworth et al. 1995; Sibik et al. 2015); alkaline or acidic STLIP products (Reichow et al. 2005, 2016); granitoid crust (Arndt et al. 2003; Yao and Mungall 2021). In all these previous works (but also in Naldrett et al. 1992; Lightfoot and Keays 2005; Sobolev et al. 2009a), the Tuklonsky picrites were considered as the parental melts of the enriched Nadezhdinsky Fm. and Lower Talnakh-type intrusions. These picrites show enriched isotopic signatures and trace elements $\left({ }^{143} \mathrm{Nd} /{ }^{144} \mathrm{Nd}_{\mathrm{i}}=0.5122\right.$ and ${ }^{87} \mathrm{Sr} /{ }^{86} \mathrm{Sr}_{\mathrm{i}}=0.7057$; $\mathrm{Nd}=7 \mathrm{ppm} ; \mathrm{Sr}=175 \mathrm{ppm}$; Sobolev et al. 2011; Yao and Mungall 2021), probably reflecting the presence of recycled sediments in the lithosphere (Lightfoot et al. 1993; Hawkesworth et al. 1995). Starting from the Tuklonsky picrite ca. $4 \%$ assimilation of Proterozoic granitoids after $60 \%$ crystallization of the initial Tuklonsky picrite can explain the isotopic signatures observed (Fig. 5a), and the Nd concentrations in 277A1 rocks (Fig.S6). We do not have a strong preference for one starting picrite against the other.

What is evident from Fig. $5 b$ is a decoupling between $\mathrm{Nd}$ and $\mathrm{Sr}$ in the TB dolerites. This is best explained by assimilation of Sr-rich lithologies, that are abundant in the Tunguska Basin sediments (marlstones, limestones, anhydrites; Pang et al. 2013), and is discussed in the following section.

From ECAFC model attempts, the lower crust (composition based on lower crustal granulite xenoliths from Udachnaya; Khoreshkova et al. 2011) appears as a less likely contaminant for the petrogenesis of most TB dolerites. Based on geobarometry, dolerites from sill 260B originated from melts that ponded in lower crustal chambers, but ECAFC modeling (starting from model C) discards their assimilation of lower crust. The overall picture emerging from assimilation modeling is that the plumbing system below the TB was complex and involved multiple magma chambers at different crustal levels, where the mantle-derived melts ponded and evolved before their emplacement in the basin.

\section{Contamination in the volcanic basin: magma-sediment interaction involving carbonates and evaporites}

Contamination trends involving $\mathrm{Sr}$ but not $\mathrm{Nd}$ such as those depicted by some of our dolerites were observed before in several studies of Siberian Traps intrusive rocks, and were interpreted as the result of contamination occurring at very shallow crustal levels, during emplacement of the sills in sedimentary host rocks (Hawkesworth et al. 1995; Arndt et al. 2003; Ripley et al. 2003, 2010; Lightfoot and Keays 2005; Keays and Lightfoot 2010; Yao and Mungall 2021). We also note that the subhorizontal Sr-trend is described by samples coming from sills and intrusions intruded in evaporitic or carbonatic host rocks (our sills 219C-E, 277E; intrusive rocks described in Hawkesworth et al. 1995; Arndt et al. 2003; Yao and Mungall 2021). Conversely, no rocks from Taimyr, where evaporitic deposits are absent, follow this trend (Reichow et al. 2016). All these observations support an origin of these signatures by interaction with the TB sediments.

Energy-constrained models involving assimilation of non-silicate lithologies are not available to date due to a lack of thermodynamic data (Heinonen et al. 2021), hence we evaluate potential assimilation paths by mixing models. In Fig. 5b, all the plotted compositions seem to converge towards a ${ }^{87} \mathrm{Sr} /{ }^{86} \mathrm{Sr}_{\mathrm{i}}$ of $0.708-0.709$. All our analyzed host rocks have isotpic signatures within this range (cf. Supplementary information 2). Most metapelites, skarn, anhydrite and marlstones analyzed by Pang et al. (2013) also show similar $\mathrm{Sr}$ isotopic values, and when analyzed, relatively radiogenic ${ }^{143} \mathrm{Nd} /{ }^{144} \mathrm{Nd}_{\mathrm{i}}(0.5124-0.5122)$, comparable with those of the dolerites. We did not measure ${ }^{143} \mathrm{Nd} /{ }^{144} \mathrm{Nd}_{\mathrm{i}}$ in the host rocks, but the concentration of $\mathrm{Nd}$ in evaporitic lithologies is much lower than that of a basaltic melt (see Fig. 4d), and because of this, assimilation of these lithologies, whatever their ${ }^{143} \mathrm{Nd} /{ }^{144} \mathrm{Nd}$ ratio, would be unable to change the $\mathrm{Nd}$ isotopic signature of the initial melt significantly. As a result, a contamination trend that affects only $\mathrm{Sr}$ is produced. In support of this, while there is a rough positive correlation between $\mathrm{Sr}$ and ${ }^{87} \mathrm{Sr} /{ }^{86} \mathrm{Sr}$ in the dataset (Fig. 5b), a plot of Nd vs. ${ }^{143} \mathrm{Nd} /{ }^{144} \mathrm{Nd}$ does not show any correlation (except for sill 277A1 rocks; Fig. S6).

Mixing lines can be calculated with different starting compositions, as illustrated in Fig. 5b. Up to 7\% uptake of marlstone can account for the $\mathrm{Sr}$ enrichment. From massbalance calculations, addition of $7 \%$ marlstone does not significantly change the major element composition of the magma. On the contrary, similar amounts of assimilated dolostone or anhydrite are expected to concomitantly enrich the magmas in Ca. Assimilation via melting or chemical dissolution of anhydrite would also enrich them in $\mathrm{S}$, not only in $\mathrm{Sr}$ (Iacono-Marziano et al. 2017). For instance, Srrich dykes of the Central Atlantic Magmatic Province in Portugal, whose compositions were modeled with a simple mixing of up to $20 \%$ limestone- $80 \%$ basalt, result in strong $\mathrm{Ca}$ and $\mathrm{Sr}$ enrichment in the most contaminated rocks (Callegaro et al. 2014). Conversely, the TB dolerites show no $\mathrm{Ca}$ enrichment and $\mathrm{Sr}$ does not reach $10^{3} \mathrm{ppm}$ levels. 
During assimilation of carbonate rocks, whole-rock $\mathrm{Ca}$ can be buffered by FC of Ca-rich minerals (e.g. augite or plagioclase; Whitley et al. 2020), and might be recorded by enrichment in $\mathrm{Ca}$ in the whole rocks or phenocrysts (e.g. Wenzel et al. 2001, high Ca in olivine). We do not see these effects in the mineral chemistry. Furthermore, there is no evidence of melting of the country rocks at the contacts, at least for the sills sampled. Black et al. (2014) and Yao and Mungall (2021) calculated evaporite assimilation around $0.08-0.25 \mathrm{wt} \%$ from isotopic analyses of sulfur on STLIP intrusive rocks. Bulk assimilation of carbonatic and evaporitic lithologies might indeed be limited to these very low amounts also in the TB dolerites. Rather, there is evidence for metasomatic late-stage interaction with the host rocks, such as (a) the presence of hydrothermal veins (with carbonates, sulfates, scapolite) cutting through the dolerites, (b) enrichment of mobile elements derived from the host rocks (e.g. Sr, Ba, Na, K; Fig. 9 and S11); (c) petrographic and geochemical evidence of hydrothermal alteration in the leucocratic enclave from sill 219D (219/2007.0B; Figs.S2; S3; S8), which plots to the radiogenic end of the Sr-trend; (d) presence of small (up to $500 \mu \mathrm{m}$ ) evolved interstitial pockets with biotite and euhedral quartz, texturally suggesting a hydrothermal origin. Several studies have shown that interaction between magma and evaporitic/carbonatic host rocks can take place by various processes besides direct melting or bulk assimilation, e.g. brine-borne diffusive transfer, hydrothermalism, or chemical dissolution (Ripley et al. 2003; Li et al. 2009; Deegan et al. 2010; Pang et al. 2013; Schofield et al. 2014; Mata et al. 2015; Iacono-Marziano et al. 2017; Yudovskaya et al. 2018; Heimdal et al. 2019).
In-situ interaction with halite-dominated host rocks deserves separate attention. Assimilation of halite is not very effective in modifying $\mathrm{Sr}$ isotopic signatures of the dolerites, but it can strongly affect $\mathrm{Na}, \mathrm{K}$ and $\mathrm{Cl}$ concentrations. Dolerites from borehole 260 and 275, and some samples from sill 219D show a trend of increasing alkali contents with decreasing silica in the TAS diagram (Fig. 3c). This is opposite to the positive trend shown by the other dolerites, reflecting evolution by fractional crystallization and crustal assimilation. We calculated simple mixing models between the more primitive, less alkali-rich 260 dolerite and halite. The trend shown by the samples is best reproduced by mixing of up to $7 \mathrm{wt} . \%$ with an impure salt composition (Pang et al. 2013), containing high alkali (31 wt.\%), but also some silica (6 wt.\%). We do not have data on wholerock $\mathrm{Cl}$ concentrations, but preliminary element mapping on biotites from evolved interstitial pockets in the TB sills revealed high concentrations of $\mathrm{Cl}$ at the crystal rims, similar to Heimdal et al. (2019). This potentially reflects formation of a Cl-rich fluid and elemental transfer via a hydrous fluid, as observed by Pang et al. (2013) for aureoles surrounding mafic sills at Norilsk. Ivanov et al. (2008) put forward that derivation from an arc mantle source would explain many geochemical features observed for the STLIP, for example the Sr positive anomaly and the presence of primary micas in the basalts. Alternatively, $\mathrm{Sr}$ enrichment can be explained by crustal assimilation (e.g., Wooden et al. 1993). We note that the modeled trace element compositions of the parental melts produced by a mantle source enriched with recycled crust (Models B-C) lack the $\mathrm{Sr}$ and $\mathrm{K}$ positive anomalies observed for most TB dolerites. We have shown how assimilation of marlstone and late-stage interaction with evaporitic
Fig. 9 Schematic N-S crosssection across the Tunguska basin illustrates the petrogenesis of the TB dolerites (horizontal and vertical scales non homogeneous). Melting of a mixed peridotitic and pyroxenitic source with recycled lower crustal domains (1) produced picrites that assimilated small amounts of granitoids and metapelites while ponding in upper crustal magma chambers (2). Further interaction with host rocks (marlstones and evaporites) after emplacement within the sedimentary basin enriched the dolerites in $\mathrm{Sr}, \mathrm{Cl}, \mathrm{Na}(3)$. The sills are color-coded suggesting the proposed correlations with the Norilsk chemostratigraphy

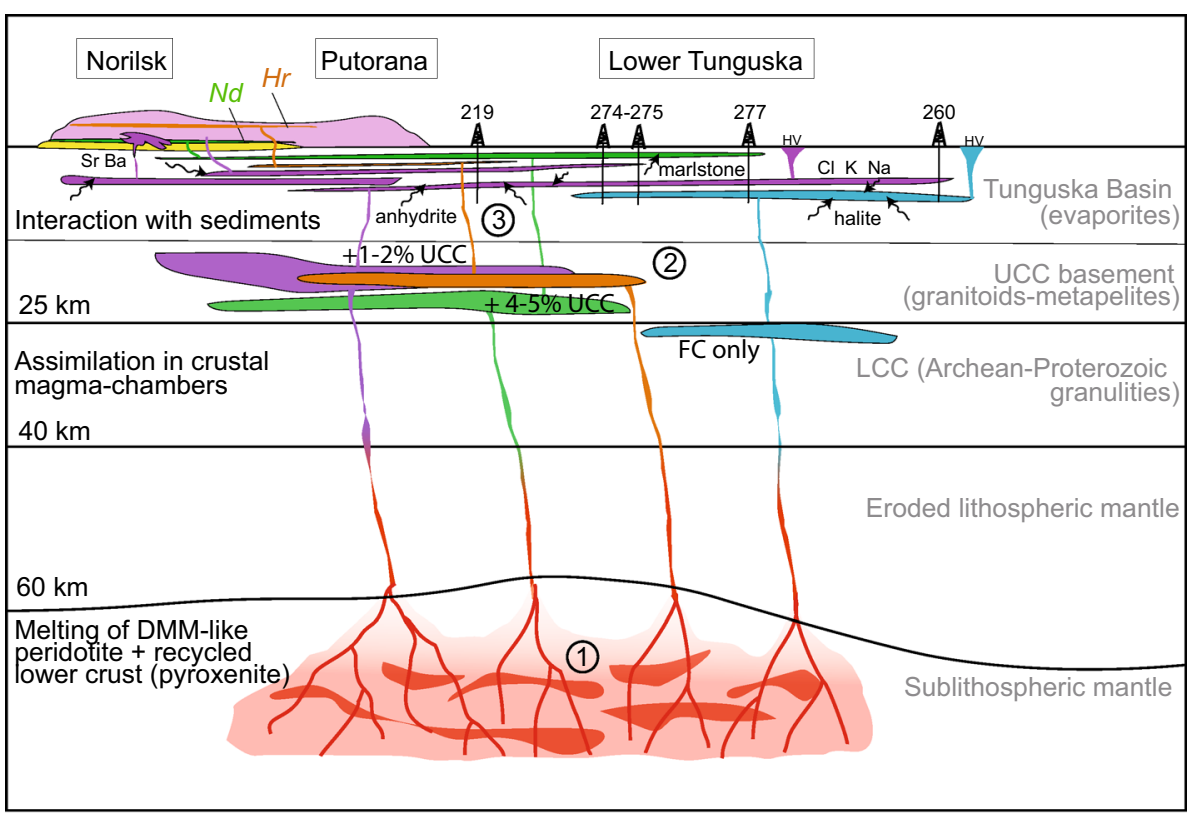


lithologies can enrich $\mathrm{Sr}$ and $\mathrm{K}$ in the basalts, hence $\mathrm{Sr}$ concentration and the presence of biotite are not good proxies of mantle source composition in the STLIP.

The TB dolerites show evidence of contamination with marlstone and additional interaction with evaporitic host rocks, potentially via circulation of fluids produced within the metamorphic aureoles around the sills. We find evidence of this signature in sills from all the investigated boreholes, located across all the Tunguska Basin. These new data are the first to demonstrate that interaction with evaporites did not occur exclusively around sills (Pang et al. 2013) and large intrusions (Naldrett et al. 1992; Arndt et al. 2003; Ripley et al. 2010; Yao and Mungall 2021) of the Norilsk area, but was a widespread process in the STLIP plumbing system, as previously suggested by Svensen et al. (2009, 2018).

\section{Relative chronology and potential implications}

The shallowest sill analyzed, 277A1, located in the most central area of the STLIP, is chemostratigraphically the oldest of all the considered sills, and 260B the youngest (potentially younger than the STLIP main phase; Ivanov et al. 2013). All the other sills are correlated with the Upper Sequence activity of the STLIP, and in particular, sills 219C-E, 274C and 277B-E, correlate best with the Morongovsky-Mokulaevsky Fm. and the Norilsk 5A intrusives. These sills represent not only the most voluminous magma-type in the analyzed boreholes (minumum $811 \mathrm{~m}$ of cumulative thickness), but also intrude exclusively evaporites (rock salt, carbonates and marls), and show clear signs of interaction with these host rocks. Svensen et al. (2018) calculated through thermal modeling that the contact metamorphic aureoles produced by cooling of the sills can generate 52-80 tons of $\mathrm{CO}_{2} \mathrm{~m}^{-2}$. On a basin-wide perspective, this means that only $0.7-1.2 \%$ of the total area in the Tunguska Basin (i.e. an area of $12-19000 \mathrm{~km}^{2}$ out of a region in excess of $1.5 \times 10^{6} \mathrm{~km}^{2}$ encompassed by the sill complex) is sufficient to generate $1000 \mathrm{Gt} \mathrm{CO}_{2}$. The observed shallow level magma-sediment interaction with limestones and evaporites supports these calculations with chemical and petrographic evidence. It should be noted that widespread occurrence of explosive vents rooted at the sills and tephra troughout the Tunguska basin (Svensen et al. 2009, 2018; Jerram et al. 2016; Polozov et al. 2016) supports the notion of discharge of thermogenic gases following sill emplacemement and associated magmasediment interaction.

Based on magnetostratigraphic evidence, Pavlov et al. (2019) proposed that the Norilsk-type 5A intrusions are coeval or nearly coeval with the boundary between the Morongovsky and Mokulaevsky Fm. In turn, some of the Norilsk-type intrusions overlap in time with the extinction interval (Burgess and Bowring 2015). Because a significant portion of the TB sills correlate geochemically with Mr-Mk
Formations and the Norilsk-type 5A intrusions, it is intriguing to think that they might also be coeval. This hyporthesis could be tested in future works by precise U-Pb dating. If confirmed, it might mean that this brief, voluminous pulse of magmatism was not restricted to the Norilsk area, but can be tracked all across the central Tunguska Basin, where there is widespread evidence for magma-sediment interaction and high potential for thermogenic gas production.

According to Burgess et al. (2017), there is a shift in style of STLIP activity from effusive (phase 1) to intrusive (phase 2), and the beginning of phase 2 coincides in time with the End-Permian extinction as dated at the GSSP in Meishan, China (between 251.941 \pm 0.037 and $251.880 \pm 0.031 \mathrm{Ma}$; Burgess et al. 2014). However, most dated sills in the TB postdate the extinction interval, and the extinction-triggering portion of the STLIP must be a currently unidentified intrusive subinterval. Three $\mathrm{U}-\mathrm{Pb}$ zircon ages were published by Burgess and Bowring (2015) for the Norilsk intrusion (G22-105-2: 251.64 $\pm 0.10 / 0.12 / 0.30 \mathrm{Ma}$; G22-63-5: 251.907 $\pm 0.067 / 0.094 / 0.29 \mathrm{Ma} ;$ G22-65-0: $251.813 \pm 0.065 / 0.092 / 0.28 \mathrm{Ma})$. The oldest age overlaps the extinction interval. From the geochemical correlations presented here, many of the sills buried below the Tunguska basin could be good candidates for the unidentified intrusive subinterval called for by Burgess et al. (2017), responsible for outstanding thermogenic gas discharge to the end-Permian atmosphere. However, in absence of high-precision geochronology data, this link remains speculative, because geochemical correlation might not necessarily mean age concurrence. For instance, intrusions from Taimyr interpreted to have a Norilsk-type 5A signature, were dated by ${ }^{40} \mathrm{Ar} /{ }^{39} \mathrm{Ar}$ to $\sim 247 \mathrm{Ma}$ (Reichow et al. 2016), i.e. younger than the ages shown by the intrusions in the Norilsk region (Burgess et al. 2017). It should be noted however that this age has a very large uncertainty and that these rocks are geochemically different from the sills presented here that correlate with Norilsk-type 5A intrusives (e.g. in $\mathrm{Zr} / \mathrm{Y}-\mathrm{Nb} / \mathrm{Y}$; Fig.S9). We also stress that, (1) no U-Pb ages were obtained by Burgess and Bowring (2015) from the tholeiitic lava Formations in Norilsk; (2) none of the 17 ages published by Burgess and Bowring (2015) was produced from samples of the sills studied here, and (3) full geochemical data are not available for the dated sills, except for sill A10-23.1 from Bratsk, previously studied by Black et al. (2014), which is compositionally very different from all the sills included in our dataset (it correlates with the evolved portion of the Tolstomysovskii sill of Ivanov et al. 2008; Fig. 3). As put forward by Burgess and Bowring (2015), the beginning of intrusive activity throughout the STLIP is unconstrained, and future $\mathrm{U}-\mathrm{Pb}$ geochronology endeavors should focus on the sills buried beneath the surface in the Tunguska Basin, despite their mafic composition. High-precision $\mathrm{U}-\mathrm{Pb}$ data were successfully obtained on mafic sills in sedimentary 
basins from other LIPs (Greber et al. 2020; Davies et al. 2021), where zircon and baddeleyite crystallized in evolved interstitial pockets similar to those observed for the TB dolerites.

\section{Concluding remarks}

Deep sills intruded into the Tunguska Basin are low-Ti, tholeiitic dolerites geochemically similar to the Upper Series lavas of the Siberian Traps LIP. Sill parental melts are most likely picrites derived by extensive melting of a mantle source with recycled crustal components below a thinned lithosphere $(80-50 \mathrm{~km})$, within the spinel stability field. The recycled components, most likely foundered or subducted lower crustal domains, were potentially represented by pyroxenites. The parental melts underwent opensystem evolution in upper custal magma chambers, assimilating from 1 to $5 \%$ granitoids and metapelites from the Proterozoic basement. Some sills were emplaced within the Tunguska Basin sedimentary sequence as a single pulse, followed by closed-system crystal fractionation, producing slash-shaped or I-shaped compositional profiles. Others show evidence for magma-mixing in their crystal cargo (inverse zoning) or turbulence caused by replenishment (autholiths), resulting in D- or complex-shaped profiles. Most sills show evidence for interaction with volatile-rich host rocks (marlstone, carbonate, anhydrite, and halite). Widespread occurrence of explosive pipes throughout the Tunguska basin suggest that this interaction led to thermogenic gas production and discharge. On the basis of isotope and trace element geochemistry we conclude that a) sill 277A1correlates with the Lower Talnakh-type 5B intrusions and the Nadezhdinsky lava formation; b) sill 219B correlates with the Kharaelakhsky (Hr) lava Formation and the Ambarninsky type II dolerites; c) sill 260B correlates with the Usol'skii sill, and is probably younger than all the lava formations defined for the Norilsk area; d) all the remaining sills correlate with Upper sequence lavas and, more specifically, sills 219C-E, 274C and 277B-E correlate with MorongovskyMokulaevsky lava Formations and with Norilsk-type 5A intrusions. This latter magma-type is recorded in at least three boreholes across the Tunguska Basins, is the most voluminous, and shows evidence for interaction with volatile-rich host rocks. Future high-precision geochronology will test the hypothesis presented here that these sills represent the hitherto unidentified early intrusive phase of STLIP responsible for extensive thermogenic gas production and discharge impacting the end-Permian atmosphere.

Supplementary Information The online version contains supplementary material available at https://doi.org/10.1007/s00410-021-01807-3.
Acknowledgements We are grateful to Y. Ronen (University of Bergen) for isotope analyses and to G.B. Fjeld and M.S. Naoroz for laboratory assistance. Eric Brown is thanked for discussions on the use of REEBOX PRO and Jussi Heinonen for discussions on the use of the Magma Chamber Simulator. Luca Ziberna is thanked for help with mineral chemistry interpretation. Othmar Müntener is thanked for his insightful editorial handling. Christian Tegner and an anonymous reviewer are acknowledged for a thought-provoking revision that significantly improved the manuscript.

Author contributions SC prepared the samples, interpreted the data and wrote the manuscript. AP, OVS, NAI, NVM sampled the boreholes. HHS, DAJ, SP, FMD, AGP, and ERN contributed to the interpretation of data with insights and discussions and helped with manuscript preparation.

Funding Open access funding provided by University of Oslo (incl Oslo University Hospital). This research is funded by the Research Council of Norway Yngeforsktalenter project "MAPLES" (project number 301096 to SC). SC, HHS, DAJ, ERN, AP and SP are supported by the Research Council of Norway through its Centres of Excellence funding scheme, project number 223272. FMD is supported by the Swedish Research Council (Vetenskapsrådet, grant number 2018-04933).

Data availability All the available data accompany the manuscript.

Open Access This article is licensed under a Creative Commons Attribution 4.0 International License, which permits use, sharing, adaptation, distribution and reproduction in any medium or format, as long as you give appropriate credit to the original author(s) and the source, provide a link to the Creative Commons licence, and indicate if changes were made. The images or other third party material in this article are included in the article's Creative Commons licence, unless indicated otherwise in a credit line to the material. If material is not included in the article's Creative Commons licence and your intended use is not permitted by statutory regulation or exceeds the permitted use, you will need to obtain permission directly from the copyright holder. To view a copy of this licence, visit http://creativecommons.org/licenses/by/4.0/.

\section{References}

Aarnes I, Podladchikov YY, Neumann E-R (2008) Post-emplacement melt flow induced by thermal stresses: implications for differentiation in sills. Earth Planet Sci Lett 276:152-166. https://doi. org/10.1016/j.eps1.2008.09.016

Arndt NT, Chauvel C, Czamanske G, Fedorenko VA (1998) Two mantle sources, two plumbing systems: tholeiitic and alkaline magmatism of the Maymecha River basin, Siberian flood volcanic province. Contrib Miner Petrol 133:297-313. https://doi.org/10. 1007/s004100050453

Arndt NT, Czamanske GK, Walker RJ, Chauvel C, Fedorenko VA (2003) Geochemistry and origin of the intrusive hosts of the Noril'sk-Talnakh Cu-Ni-PGE sulfide deposits. Econ Geol 98:495-515. https://doi.org/10.2113/gsecongeo.98.3.495

Augland LE, Ryabov VV, Vernikovsky VA, Planke S, Polozov AG, Callegaro S, Jerram DA, Svensen HH (2019) The main pulse of the Siberian Traps expanded in size and composition. Sci Rep 9:1-12. https://doi.org/10.1038/s41598-019-54023-2

Bédard JH (2014) Parameterizations of calcic clinopyroxene-melt trace element partition coefficients. Geochem Geophys Geosyst 15:303-336. https://doi.org/10.1002/2013GC005112 
Bédard JH, Saumur B-M, Williamson M-C, Tegner C, Troll VR, Deegan FM, Evenchick CA, Grasby SE, Dewing K (2020) Geochemical database of Cretaceous High Arctic Large Igneous Province magmatic rocks, Arctic Canada. Geological Survey of Canada, Open File. https://doi.org/10.4095/327829

Black BA, Elkins-Tanton LT, Rowe MC, Peate IU (2012) Magnitude and consequences of volatile release from the Siberian Traps. Earth Planet Sci Lett 317-318:363-373. https://doi.org/10. 1016/j.epsl.2011.12.001

Black BA, Hauri EH, Elkins-Tanton LT, Brown SM (2014) Sulfur isotopic evidence for sources of volatiles in Siberian Traps magmas. Earth Planet Sci Lett 394:58-69. https://doi.org/10.1016/j.epsl. 2014.02.057

Bohrson WA, Spera FJ, Heinonen JS, Brown GA, Scruggs MA, Adams JV, Takach MK, Zeff G, Suikkanen E (2020) Diagnosing open system magmatic processes using the Magma Chamber Simulator (MCS): part I-major elements and phase equilibria. Contrib Miner Petrol 175:104. https://doi.org/10.1007/s00410-020-01722

Brown EL, Lesher CE (2016) REEBOX PRO: A forward model simulating melting of thermally and lithologically variable upwelling mantle. Geochem Geophys Geosyst 17:3929-3968. https://doi. org/10.1002/2016GC006579

Burgess SD, Bowring SA (2015) High-precision geochronology confirms voluminous magmatism before, during, and after Earth's most severe extinction. Sci Adv 1:e150470. https://doi.org/10. 1126/sciadv. 1500470

Burgess SD, Bowring S, Shen S (2014) High-precision timeline for Earth's most severe extinction. Proc Nat Acad Sci 111:33163321. https://doi.org/10.1073/pnas.1317692111

Burgess SD, Muirhead JD, Bowring SA (2017) Initial pulse of Siberian Traps sills as the trigger of the end-Permian mass extinction. Nat Commun 8:1-4. https://doi.org/10.1038/s41467-017-00083-9

Callegaro S, Rapaille C, Marzoli A, Bertrand H, Chiaradia M, Reisberg L, Bellieni G, Martins L, Madeira J, Mata J, Youbi N, De Min A, Azevedo MR, Bensalah MK (2014) Enriched mantle source for the Central Atlantic magmatic province: new supporting evidence from southwestern Europe. Lithos 188:15-32. https://doi.org/10.1016/j.lithos.2013.10.021

Callegaro S, Marzoli A, Bertrand H, Blichert-Toft J, Reisberg L, Cavazzini G, Jourdan F, Davies JHFL, Parisio L, Bouchet R, Paul A, Schaltegger U, Chiaradia M (2017) Geochemical constraints provided by the Freetown Layered Complex (Sierra Leone) on the origin of high-ti tholeiitic CAMP magmas. J Petrol 58:1811-1840. https://doi.org/10.1093/petrology/egx073

Czamanske GK, Wooden JL, Walker RJ, Fedorenko VA, Simonov ON, Budahn JR, Siems DF (2000) Geochemical, isotopic, and SHRIMP age data for Percambrian basement rocks, Permian volcanic rocks, and sedimentary host rocks to the ore-bearing intrusions, Noril'sk-Talnakh district, Siberian Russia. Int Geol Rev 42(10):895-927. https://doi.org/10.1080/0020681000 9465117

Dal Corso J, Mills BJW, Chu D, Newton RJ, Mather TA, Shu W, Wu Y, Tong J, Wignall PB (2020) Permo-Triassic boundary carbon and mercury cycling linked to terrestrial ecosystem collapse. Nat Commun 11:2962. https://doi.org/10.1038/s41467-020-16725-4

Davies JHFL, Marzoli A, Bertrand H, Youbi N, Ernesto M, Greber ND, Ackerson M, Simpson G, Bouvier AS, Baumgartner L, Pettke T, Farina F, Ahrenstedt HV, Schaltegger U (2021) Zircon petrochronology in large igneous provinces reveals upper crustal contamination processes: new $\mathrm{U}-\mathrm{Pb}$ ages, $\mathrm{Hf}$ and $\mathrm{O}$ isotopes, and trace elements from the Central Atlantic magmatic province (CAMP). Contrib Mineral Petrol 176:9. https://doi.org/10.1007/ s00410-020-01765-2

Deegan FM, Troll VR, Freda C, Misiti V, Chadwick JP, McLeod CL, Davidson JP (2010) Magma-Carbonate interaction processes and associated $\mathrm{CO}_{2}$ release at Merapi Volcano, Indonesia: insights from experimental petrology. J Petrol 51:1027-1051. https://doi. org/10.1093/petrology/egq010

Egorova V, Latypov R (2013) Mafic-ultramafic sills: New insights from M- and S-shaped mineral and whole-rock compositional profiles. J Petrol 54:2155-2191. https://doi.org/10.1093/petrology/egt045

Elkins-Tanton LT, Draper DS, Agee CB, Jewell J, Thorpe A, Hess PC (2007) The last lavas erupted during the main phase of the Siberian flood volcanic province: results from experimental petrology. Contrib Mineral Petrol 153:191-209. https://doi.org/ 10.1007/s00410-006-0140-1

Fedorenko VA, Lightfoot PC, Naldrett AJ, Czamanske GK, Hawkesworth CJ, Wooden JL, Ebel DS (1996) Petrogenesis of the floodbasalt sequence at Noril'sk, north central Siberia. Int Geol Rev 38:99-135. https://doi.org/10.1080/00206819709465327

Fitton JG, Saunders AD, Norry MJ et al (1997) Thermal and chemical structure of the Iceland plume. Earth Planet Sci Lett 153:197208. https://doi.org/10.1016/S0012-821X(97)00170-2

Galerne CY, Neumann ER, Aarnes I, Planke S (2010) Magmatic differentiation processes in saucer-shaped sills: evidence from the Golden Valley Sill in the Karoo Basin, South Africa. Geosphere 6:163-188. https://doi.org/10.1130/GES00500.1

Gibb FGF, Henderson CMB (1992) Convection and crystal settling in sills. Contrib Miner Petrol 109(4):538-545. https://doi.org/10. 1007/BF00306555

Greber ND, Davies JHFL, Gaynor SP, Jourdan F, Bertrand H, Schaltegger $\mathrm{U}(2020)$ New high precision $\mathrm{U}-\mathrm{Pb}$ ages and $\mathrm{Hf}$ isotope data from the Karoo large igneous province; implications for pulsed magmatism and early Toarcian environmental perturbations. Results Geochemistry 1:100005. https://doi.org/10.1016/j.ringeo. 2020.100005

Hawkesworth CJ, Lightfoot PC, Fedorenko VA, Blake S, Naldrett AJ, Doherty W, Gorbachev NS (1995) Magma differentiation and mineralisation in the Siberian continental flood basalts. Lithos 34:61-88. https://doi.org/10.1016/0024-4937(95)90011-X

Heimdal TH, Callegaro S, Svensen HH, Jones MT, Pereira E, Planke S (2019) Evidence for magma-evaporite interactions during the emplacement of the Central Atlantic Magmatic Province (CAMP) in Brazil. Earth Planet Sci Lett 506:476-492. https:// doi.org/10.1016/j.epsl.2018.11.018

Heinonen JS, Luttinen AV, Bohrson WA (2016) Enriched continental flood basalts from depleted mantle melts: modeling the lithospheric contamination of Karoo lavas from Antarctica. Contrib Miner Petrol 171(9):1-22. https://doi.org/10.1007/ s00410-015-1214-8

Heinonen JS, Bohrson WA, Spera FJ, Brown GA, Scruggs MA, Adams JV (2020) Diagnosing open-system magmatic processes using the Magma Chamber Simulator (MCS): part II-trace elements and isotopes. Contrib Mineral Petrol 175:105. https://doi.org/10. 1007/s00410-020-01718-9

Heinonen JS, Iles KA, Heinonen A, Fred R, Virtanen VJ, Bohrson WA, Spera FJ (2021) From Binary mixing to magma chamber simulator: geochemical modeling of assimilation in magmatic systems. In: Masotta M, Beier C, Mollo S (eds) Crustal magmatic system evolution: anatomy, architecture and physico-chemical processes. Wiley. https://doi.org/10.1002/essoar.10504606.2

Herzberg C, Asimow PD (2015) PRIMELT3 MEGA.XLSM software for primary magma calculation: Peridotite primary magma $\mathrm{MgO}$ contents from the liquidus to the solidus. Geochem Geophys Geosyst 16:563-578. https://doi.org/10.1002/2014GC005631

Hirose K, Kushiro I (1993) Partial melting of dry peridotites at high pressures: determination of compositions of melts segregated from peridotite using aggreates of diamond. Earth Planet Sci Lett 114:477-489. https://doi.org/10.1016/0012-821X(93)90077-M

Horan MF, Walker RJ, Fedorenko VA, Czamanske GK (1995) Osmium and neodymium isotopic constraints on the temporal and spatial evolution of Siberian flood basalt sources. Geochim Cosmochim 
Acta 59:5159-5168. https://doi.org/10.1016/0016-7037(96) 89674-8

Iacono-Marziano G, Ferraina C, Gaillard F, Di Carlo I, Arndt NT (2017) Assimilation of sulfate and carbonaceous rocks: experimental study, thermodynamic modeling and application to the Noril'sk-Talnakh region (Russia). Ore Geol Rev 90:399-413. https://doi.org/10.1016/j.oregeorev.2017.04.027

Irvine TN, Baragar WRA (1971) A guide chemical classification of the common volcanic rock. Canad J Earth Sci 8:523-548. https://doi. org/10.1139/e71-055

Ivanov AV (2007) Evaluation of different models for the origin of the Siberian Traps. In: Foulger GR, Jurdy DM (eds) Plates, plumes and planetary processes. Geol Soc Am Spec Pap 430:669-691. https://doi.org/10.1130/2007.2430(31)

Ivanov AV, Balyshev SV (2005) Mass flux across the lower-upper mantle boundary: Vigorous, absent, or limited? In: Foulger GR, Natland JH, Presnall DC, Anderson DL (eds) Plates, plumes, and paradigms. Geol Soc Am Spec Pap 388:327-346. https:// doi.org/10.1130/SPE388

Ivanov AV, Demonterova EI, Rasskazov SV, Yasnygina TA (2008) Low-Ti melts from the southeastern Siberian traps large igneous province: Evidence for a water-rich mantle source? J Earth Syst Sci 117:1-21. https://doi.org/10.1007/s12040-008-0008-z

Ivanov AV, He H, Yan L, Ryabov VV, Shevko AY, Palesskii SV, Nikolaeva IV (2013) Siberian Traps large igneous province: Evidence for two flood basalt pulses around the Permo-Triassic boundary and in the Middle Triassic, and contemporaneous granitic magmatism. Earth-Sci Rev 122:58-76. https://doi.org/10. 1016/j.earscirev.2013.04.001

Jahn BM, Gruau G, Capdevila R, Cornichet J, Nemchin A, Pidgeon R, Rudnikc VA (1998) Archean crustal evolution of the Aldan Shield, Siberia: geochemical and isotopic constraints. Precambrian Res 91:333-363. https://doi.org/10.1016/S03019268(98)00057-6

Jerram DA, Svensen HH, Planke S, Polozov AG, Torsvik TH (2016) The onset of flood volcanism in the north-western part of the Siberian Traps: explosive volcanism versus effusive lava flows. Palaeogeogr Palaeoclimatol Palaeoecol 441:38-50. https://doi. org/10.1016/j.palaeo.2015.04.022

Keays RR, Lightfoot PC (2010) Crustal sulfur is required to form magmatic $\mathrm{Ni}-\mathrm{Cu}$ sulfide deposits: evidence from chalcophile element signatures of Siberian and Deccan Trap basalts. Miner Depos 45:241-257. https://doi.org/10.1007/ s00126-009-0271-1

Kiselev AI, Yarmolyuk VV, Tomshin MD, Nikiforov AV, Egorov KN (2014) Permian-Triassic traps of the east Siberian Craton: The problem of estimation of the sources of phanerozoic intraplate magmatism. Dokl Earth Sci 455:299-305. https://doi.org/10. 1134/S1028334X14030192

Kontorovich AE, Moskvin VI, Bostikov OI, Danilova VP, Fomin AN, Fomichev AS, Kostyreva EA, Melenevsky VN (1997) Main oil source formations of the West Siberian Basin. Pet Geosci 3(4):343-358. https://doi.org/10.1144/petgeo.3.4.343

Koreshkova MY, Downes H, Levsky LK, Vladykin NV (2011) Petrology and geochemistry of granulite xenoliths from Udachnaya and Komsomolskaya kimberlite pipes, Siberia. J Petrol 52:18571885. https://doi.org/10.1093/petrology/egr033

Krivolutskaya N, Belyatsky B, Gongalsky B, Dolgal A, Lapkovsky A, Bayanova TB (2020) Petrographical and geochemical characteristics of magmatic rocks in the Northwestern Siberian Traps Province, Kulyumber River Valley. Part II: rocks of the Kulyumber Site. Minerals 10:415. https://doi.org/10.3390/min10050415

Latypov RM (2003) The origin of marginal compositional reversals in basic-ultrabasic sills and layered intrusions by soret fractionation. J Petrol 44:1579-1618. https://doi.org/10.1093/petrology/egg050
Le Maitre RW (2002) Igneous rocks: a classification and glossary of terms. Cambridge University Press, Cambridge. https://doi.org/ 10.1017/CBO9780511535581

Li C, Ripley EM, Naldrett AJ, Schmitt AK, Moore CH (2009) Magmatic anhydrite-sulfide assemblages in the plumbing system of the Siberian Traps. Geology 37:259-262. https://doi.org/10. 1130/G25355A.1

Lightfoot PC, Keays RR (2005) Siderophile and chalcophile metal variations in flood basalts from the Siberian trap, Noril'sk region: Implications for the origin of the Ni-Cu-PGE sulfide ores. Econ Geol 100:439-462. https://doi.org/10.2113/gsecongeo.100.3.439

Lightfoot PC, Naldrett AJ, Gorbachev NS, Doherty W, Fedorenko VA (1990) Geochemistry of the Siberian Trap of the Noril'sk area, USSR, with implications for the relative contributions of crust and mantle to flood basalt magmatism. Contrib Mineral Petrol 104:631-644. https://doi.org/10.1007/BF01167284

Lightfoot PC, Hawkesworth CJ, Hergt J, Naldrett AJ, Gorbachev NS, Fedorenko VA, Doherty W (1993) Remobilisation of the continental lithosphere by a mantle plume: from picritic and tholeiitic iavas of the Norilsk District, Siberian Trap, Russia. Contrib Mineral Petrol 114:171-188. https://doi.org/10.1007/BF00307754

Luttinen AV (2018) Bilateral geochemical asymmetry in the Karoo large igneous province. Sci Rep 8:5223. https://doi.org/10.1038/ s41598-018-23661-3

Marsh BD (2002) On bimodal differentiation by solidification front instability in basaltic magmas, part 1: basic mechanics. Geochim Cosmochim Acta 66:2211-2229. https://doi.org/10.1016/S00167037(02)00905-5

Marzoli A, Callegaro S, Dal Corso J, Davies JHFL, Chiaradia M, Youbi N, Bertrand H, Reisberg L, Merle R, Jourdan F (2018) The Central Atlantic Magmatic Province (CAMP): a review. In: Tanner L (ed) The Late Triassic World. Topics in Geobiology 46. Springer, Cham, pp 91-125. https://doi.org/10.1007/978-3-319-68009-5_4

Mata J, Alves CF, Martins L, Miranda R, Madeira J, Pimentel N, Martins S, Azevedo MR, Youbi N, De Min A, Almeida IM, Bensalah MK, Terrinha $\mathrm{P}(2015){ }^{40} \mathrm{Ar} /{ }^{39} \mathrm{Ar}$ ages and petrogenesis of the West Iberian Margin onshore magmatism at the Jurassic-Cretaceous transition: Geodynamic implications and assessment of open-system processes involving saline materials. Lithos 236-237:156-172. https://doi.org/10.1016/j.lithos. 2015.09.001

McDonough WF, Sun S-s (1995) The composition of the Earth. Chem Geol 120:223-254. https://doi.org/10.1016/0009-2541(94) 00140-4

Merlet C (1994) An accurate computer correction program for quantitative electron probe microanalysis. Mikrochim Acta 114:363-376. https://doi.org/10.1007/BF01244563

Naldrett AJ, Lightfoot PC, Fedorenko V, Doherty W, Gorbachev NS (1992) Geology and geochemistry of intrusions and flood basalts of the Noril'sk region, USSR, with implications for the origin of the Ni-Cu ores. Econ Geol 87:975-1004. https://doi.org/10. 2113/gsecongeo.87.4.975

Neave DA, Putirka KD (2017) A new clinopyroxene-liquid barometer, and implications for magma storage pressures under Icelandic rift zones. Am Miner 102:777-794. https://doi.org/10.2138/ am-2017-5968

Pang KN, Arndt NT, Svensen HH, Planke S, Polozov AG, Polteau S, Iizuka Y, Chung S-L (2013) A petrologic, geochemical and Sr-Nd isotopic study on contact metamorphism and degassing of Devonian evaporites in the Norilsk aureoles, Siberia. Contrib Mineral Petrol 165:683-704. https://doi.org/10.1007/ s00410-012-0830-9

Pavlov VE, Fluteau F, Latyshev AV, Fetisova AM, Elkins-Tanton LT, Black BA, Burgess SD, Veselovskiy RV (2019) Geomagnetic secular variations at the Permian-Triassic Boundary and pulsed magmatism during eruption of the Siberian Traps. Geochem 
Geophys Geosyst 20:773-791. https://doi.org/10.1029/2018G C007950

Pearce J, Ernst RE, Peate DW, Rogers C (2021) LIP printing: Use of immobile element proxies to characterize Large Igneous Provinces in the geologic record. Lithos 392-393:106068. https://doi. org/10.1016/j.lithos.2021.106068

Pin C, Briot D, Bassin C, Poitrasson F (1994) Concomitant separation of strontium and samarium-neodymium for isotopic analysis in silicate samples, based on specific extraction chromatography. Anal Chim Acta 298:209-217. https://doi.org/10.1016/00032670(94)00274-6

Polozov AG, Svensen HH, Planke S, Grishina SN, Fristad KE, Jerram DA (2016) The basalt pipes of the Tunguska Basin (Siberia, Russia): high temperature processes and volatile degassing into the end-Permian atmosphere. Palaeogeogr Palaeoclimatol Palaeoecol 441:51-64. https://doi.org/10.1016/j.palaeo.2015.06.035

Reichow MK, Saunders AD, White RV, Pringle MS, Al'Mukhamedov AI, Medvedev AI, Kirda NP (2002) ${ }^{40} \mathrm{Ar} /{ }^{39} \mathrm{Ar}$ dates from the West Siberian Basin: Siberian Flood Basalt Province doubled. Science 296:1846-1849. https://doi.org/10.1126/science.10716 71

Reichow MK, Saunders AD, White RV, Al'Mukhamedov AI, Medvedev AI (2005) Geochemistry and petrogenesis of basalts from the West Siberian Basin: an extension of the Permo-Triassic Siberian Traps, Russia. Lithos 79:425-452. https://doi.org/10. 1016/j.lithos.2004.09.011

Reichow MK, Pringle MS, Al'Mukhamedov AI, Allen MB, Andreichev VL, Buslov MM, Davies CE, Fedoseev GS, Fitton JG, Inger S, Medvedev AI, Mitchell C, Puchkov VN, Safonova IY, Scott RA, Saunders AD (2009) The timing and extent of the eruption of the Siberian Traps large igneous province: implications for the end-Permian environmental crisis. Earth Planet Sci Lett 277:9-20. https://doi.org/10.1016/j.epsl.2008.09.030

Reichow MK, Saunders AD, Scott RA, Millar IL, Barfod D, Pringle MS, Rogers NW, Hammond S (2016) Petrogenesis and timing of mafic magmatism, South Taimyr, Arctic Siberia: a northerly continuation of the Siberian Traps? Lithos 248-251:382-401. https://doi.org/10.1016/j.lithos.2016.01.018

Ripley EM, Lightfoot PC, Li C, Elswick ER (2003) Sulfur isotopic studies of continental flood basalts in the Noril'sk region: Implications for the association between lavas and ore-bearing intrusions. Geochim Cosmochim Acta 67:2805-2817. https://doi.org/ 10.1016/S0016-7037(03)00102-9

Ripley EM, Li C, Moore CH, Schmitt AK (2010) Micro-scale S isotope studies of the Kharaelakh intrusion, Noril'sk region, Siberia: constraints on the genesis of coexisting anhydrite and sulfide minerals. Geochim Cosmochim Acta 74:634-644. https://doi. org/10.1016/j.gca.2009.10.003

Roeder PL, Emslie RF (1970) Olivine-liquid equilibrium. Contrib Mineral Petrol 29:275-289. https://doi.org/10.1007/BF00371276

Ross P-S, Ukstins Peate I, McClintock MK, Xu YG, Skilling IP, White JDL, Houghton BF (2005) Mafic volcaniclastic deposits in flood basalt provinces: a review. J Volcanol Geotherm Res 145:281314. https://doi.org/10.1016/j.jvolgeores.2005.02.003

Rudnick RL, Gao S (2014) Composition of the Continental Crust. In: Holland HD, Turekian KK (eds) Treatise on Geochemistry, 2nd edn. Elsevier, Oxford, pp 1-51. https://doi.org/10.1016/b978-008-095975-7.00301-6

Ryabov VV, Shevko AY, Gora MP (2014) Trap magmatism and ore formation in the Siberian Noril'sk Region. Vol 1. Trap Petrology. Modern approaches in solid earth sciences. Springer, Netherlands. https://doi.org/10.1007/978-94-007-5022-7

Saunders AD, England RW, Reichow MK, White RV (2005) A mantle plume origin for the Siberian Traps: uplift and extension in the West Siberian Basin. Lithos 79:407-424. https://doi.org/10. 1016/j.lithos.2004.09.010
Schofield N, Alsop I, Warren J, Underhill JR, Lehné R, Beer W, Lukas V (2014) Mobilizing salt: magma-salt interactions. Geology 42:599-602. https://doi.org/10.1130/G35406.1

Sharma M (1997) Siberian Traps. In: Mahoney JJ, Coffin MF (eds) Large Igneous Provinces: Continental, Oceanic, and Planetary Flood Volcanism. Geophysical Monograph Series. https://doi. org/10.1029/GM100p0273

Sharma M, Basu AR, Nesterenko GV (1991) Nd-Sr isotopes, petrochemistry, and origin of the Siberian flood basalts, USSR. Geochim Cosmochim Acta 55:1183-1192. https://doi.org/10.1016/ 0016-7037(91)90177-7

Sibik S, Edmonds M, Maclennan J, Svensen H (2015) Magmas erupted during the main pulse of Siberian Traps volcanism were volatilepoor. J Petrol 56:2089-2116. https://doi.org/10.1093/petrology/ egv064

Sobolev AV, Krivolutskaya NA, Kuzmin DV (2009a) Petrology of the parental melts and mantle sources of Siberian trap magmatism. Petrology 17:253-286. https://doi.org/10.1134/S086959110 9030047

Sobolev AV, Krivolutskaya NA, Kuzmin DV, Malitch KN, Petrunin AG (2009b) Siberian meimechites: origin and relation to flood basalts and kimberlites. Russ Geol Geophys 50:999-1033. https://doi.org/10.1016/j.rgg.2009.11.002

Sobolev SV, Sobolev AV, Kuzmin DV, Krivolutskaya NA, Petrunin AG, Arndt NT, Radko VA, Vasiliev YR (2011) Linking mantle plumes, large igneous provinces and environmental catastrophes. Nature 477:312-316. https://doi.org/10.1038/nature10385

Sparks RSJ, Huppert HE, Turner JS (1984) The fluid dynamics of evolving magma chambers. Philos Trans R Soc London 310:511534. https://doi.org/10.1098/rsta.1984.0006

Spera FJ, Bohrson WA (2001) Spera, F. J., and W. A. Bohrson, Energyconstrained open-system magmatic processes, 1, General model and energy-constrained assimilation and fractional crystallization (EC-AFC) formulation. J Petrol 42:999-1018. https://doi.org/10. 1093/petrology/42.5.999

Sprain CJ, Renne PR, Vanderkluysen L, Pande K, Self S, Mittal T (2019) The eruptive tempo of Deccan volcanism in relation to the Cretaceous-Paleogene boundary. Science 80:363-866. https:// doi.org/10.1126/science.aav1446

Sun S-s, McDonough WF (1989) Chemical and isotopic systematics of oceanic basalts: implications for mantle composition and processes. In: Saunders AD, Norry MJ (eds) Magmatism in the Ocean Basins. Geological Society, Special Publications, London, pp 313-345. https://doi.org/10.1144/GSL.SP.1989.042.01.19

Suvorov VD, Melnik EA, Thybo H, Perchuć E, Parasotka BS (2006) Seismic velocity model of the crust and uppermost mantle around the Mirnyi kimberlite field in Siberia. Tectonophysics 420:167-185. https://doi.org/10.1016/j.tecto.2006.01.009

Svensen HH, Planke S, Malthe-Sørenssen A, Jamtveit B, Myklebust R, Rasmussen Eidem T, Rey SS (2004) Release of methane from a volcanic basin as a mechanism for initial Eocene global warming. Nature 429:542-545. https://doi.org/10.1038/nature02566

Svensen HH, Planke S, Polozov AG, Schmidbauer N, Corfu F, Podladchikov YY, Jamtveit B (2009) Siberian gas venting and the endPermian environmental crisis. Earth Planet Sci Lett 277:490500. https://doi.org/10.1016/j.epsl.2008.11.015

Svensen HH, Aarnes I, Podladchikov YY, Jettestuen E, Harstad CH, Planke S (2010) Sandstone dikes in dolerite sills: evidence for high-pressure gradients and sediment mobilization during solidification of magmatic sheet intrusions in sedimentary basins. Geosphere 6:211-224. https://doi.org/10.1130/GES00506.1

Svensen HH, Frolov S, Akhmanov GG, Polozov AG, Jerram DA, Shiganova OV, Melnikov NV, Iyer K, Planke S (2018) Sills and gas generation in the Siberian Traps. Phil Trans R Soc A 376:20170080. https://doi.org/10.1098/rsta.2017.0080 
Tegner C, Michelis SAT, McDonald I, Brown EL, Youbi N, Callegaro S, Lindström S, Marzoli A (2019) Mantle Dynamics of the Central Atlantic Magmatic Province (CAMP): constraints from Platinum Group, Gold and Lithophile Elements in Flood Basalts of Morocco. J Petrol 60:1621-1652. https://doi.org/10.1093/petro logy/egz041

Ulmishek GF (2001) Petroleum geology and resources of the Baykit High province, East Siberia, Russia. U.S.G.S. Bulletin 2201-F. http://geology.cr.usgs.gov/pub/bulletins/b2201-f

Vasiliev YR, Zolotukhin VV, Feoktistov GD, Prusskaya SN (2000) Evaluation of the volume and genesis of Permo-Triassic Trap magmatism on the Siberian Platform. Russ Geol Geophys 41:1696-1705

Vernikovsky VA, Pease VL, Vernikovskaya AE, Romanov AP, Gee DG, Travin AV (2003) First report of early Triassic A-type granite and syenite intrusions from Taimyr: product of the northern Eurasian superplume? Lithos 66:23-36. https://doi.org/10.1016/ S0024-4937(02)00192-5

Wang X, Wilde S, Pang C (2016) Origin of arc-like continental basalts. Implications for deep-Earth fluid cycling and tectonic discrimination. Lithos 261:5-45. https://doi.org/10.1016/j.lithos.2015. 12.014

Ware B, Jourdan F, Tohver E, Fernandes KG, Chiaradia M (2018) Primary hydrous minerals from the Karoo LIP magmas: evidence for a hydrated source component. Earth Planet Sci Lett 503:181-193. https://doi.org/10.1016/j.eps1.2018.09.017

Wenzel T, Baumgartner LP, Brügmann GE, Konnikov EG, Kislov EV (2002) Partial melting and assimilation of dolomitic xenoliths by mafic magma: The Ioko-Dovyren intrusion (North Baikal region, Russia). J Petrol 43:2049-2074. https://doi.org/10.1093/ petrology/43.11.2049
Whitley S, Halama R, Gertisser R, Preece K, Deegan FM, Troll VR (2020) Magmatic and metasomatic effects of magma-carbonate interaction recorded in calc-silicate xenoliths from Merapi volcano (Indonesia). J Petrol 61:egaa0048. https://doi.org/10.1093/ petrology/egaa048

Wooden JL, Czamanske GK, Fedorenko VA, Arndt NT, Chauvel C, Bouse RM, King BSW, Knight RJ, Siems DF (1993) Isotopic and trace-element constraints on mantle and crustal contributions to Siberian continental flood basalts, Noril'sk area, Siberia. Geochim Cosmochim Acta 57:3677-3704. https://doi.org/10.1016/ 0016-7037(93)90149-Q

Workman RK, Hart SR (2005) Major and trace element composition of the depleted MORB mantle (DMM). Earth Planet Sci Lett 231:53-72. https://doi.org/10.1016/j.eps1.2004.12.005

Yao Z-s, Mungall JE (2021) Linking the Siberian flood basalts and giant Ni-Cu-PGE sulfide deposits at Norilsk. J Geophys Res: Solid Earth 126:e2020JB020823. https://doi.org/10.1029/2020J B020823

Yudovskaya MA, Sluzhenikin SF, Costin G, Shatagin KN, Dubinina EO, Grobler DF, Ueckermann H, Kinnaird JA (2018) Anhydrite assimilation by ultramafic melts of the Bushveld Complex, and its consequences to petrology and mineralization. In: Arribas AMR, Mauk KL (eds) Metals, Minerals and Society. Society of Economic Geologists, Special Publication 21:177-206. https:// doi.org/10.5382/SP.21.09

Publisher's Note Springer Nature remains neutral with regard to jurisdictional claims in published maps and institutional affiliations. 